\title{
Dina D’Elia
}

\section{"Estote quod videtis, et accipite quod estis«: \\ evharistija pri Avreliju Avguštinu}

To je središčna misel Avguština, ko v pashalnih govorih 272 in 227 oz. evharističnih katehezah nagovarja novokrščence. Gre za dva izmed štirih govorov hiponskega škofa, namenjenih neofitom, v katerih izrecno govori o evharističnem zakramentu $(227,228,229 / \mathrm{A}, 272)$. V naši raziskavi se bomo torej ustavili le ob prvem in zadnjem izmed teh govorov. Vzporedno bomo brali ${ }^{1}$ Govor 272 (med 405 in 411 po Kr.), kjer evharistijo opredeljuje kot $m y$ sterium unitatis, in Govor 227 (412-413 oz. 416-417 po Kr.), iz katerega bo razviden drug poudarek Avguštinove teologije, in sicer evharistija kot sacramentum redemptionis. Biti to, kar evharistija predstavlja kot skrivnost edinosti, in sprejeti to, kar evharistija ponavzočuje kot zakrament odrešenja, sta glavna segmenta tega velikega mnogokotnika Avguštinovega evharističnega nauka.

V tem prispevku se želimo osredotočiti na ta vidik Avguštinovih spisov in pokazati pomenske dejavnike njegove misli: »Bodite, kar vidite, in prejmite, kar ste«, predvsem preko interpretativnega ključa leta 411. Minilo je namreč šestnajst stoletij, odkar je velika javna škofovska sinoda v Kartagini rešila dolgoletno donatistično shizmo, medtem ko se je na vidiku že pojavilo pereče vprašanje pelagijanstva, ki je po manihejstvu in donatizmu dolgo zaposlilo hiponskega misleca. Iz zornega kota te kronološke prelomnice bomo razsvetlili vpliv protidonatističnega in protipelagijanskega ozadja na Avguštinov evharistični nauk.

1 Za latinsko besedilo Govora 272 navajamo PL 38, 1246-1248, za Govor 227 pa PL 38, 1099-1101. 


\section{KONTEKSTUALIZACIJA GOVOROV 272 IN 227}

Razlagalci menijo, ${ }^{2}$ da je Avguštin imel Govor 272 bodisi na binkoštni dan (Mavrinci) bodisi za veliko noč (Wilmart, Lambot, Poque, Zwinggi) med letoma 405 in 411 (Beuron, Bori, Kunzelmann), medtem ko kraj ni znan. Glavna tema govora je zakrament Kristusovega telesa in krvi. Govor 227 pa naj bi hiponski škof imel na velikonočno jutro (Poque) ali popoldne (Pellegrino) v Hiponu kot tradicionalno katehezo za novokrščence, ki so se drugič udeležili evharistične daritve. Za veliko noč je škof namreč običajno govoril zjutraj, pri maši po vigiliji, in popoldne. ${ }^{3}$ Kronološko Beuron Govor 227 postavlja v leta 412-413 ali 416 oz. 417. Prvi del govora se osredotoči na evharistični kruh kot na znamenje enosti med verniki, drugi del pa razlaga darovanjski del sv. maše.

V nadaljevanju bomo skušali poglobiti ozadje teh dveh govorov, in sicer z različnih zornih kotov in z namenom, da bi čimbolj osvetlili temo evharistije pri Avguštinu. Še enkrat velja omeniti, da gre za zelo omejen poskus predstavitve njegovega evharističnega nauka, ki je sam po sebi zelo celosten, saj je Avguštin kot učitelj Cerkve razmišljal o evharistiji kot teolog, pastir, pa tudi kot ekseget, zato se vsi ti vidiki razumevanja in doživljanja samega zakramenta zelo prepletajo.

\section{Liturgično ozadje}

Ustavimo se najprej pri liturgičnem kontekstu izbranih govorov. V sklopu Avguštinovega oznanjevanja posebno pozornost pritegnejo t.i. pashalni govori, ki predstavljajo osrednjo skrivnost krščanskega življenja. ${ }^{4} \mathrm{~V}$ prvih stoletjih so zakramente uvajanja podeljevali predvsem $\mathrm{v}$ času velikonočnih praznikov, ${ }^{5}$ zato lahko, izhajajoč iz omenjenih govorov, postavimo liturgični in zakramentalni okvir Avguštinovega nauka o evharistiji. ${ }^{6}$ Hiponski škof na poseben način posreduje svoje misli o evharistiji v govorih, ki jih je imel za novokrščene, t.i. infantes, za veliko noč, ${ }^{7}$ ne glede na to, da so ti govori krat-

2 Opere di Sant'Agostino, zv. IV/2, 1043.

3 Pellegrino, Introduzione generale, XV.

4 Poque, Introduction, 9.

5 Uvajanje v krščansko skrivnost oz. mistagogija je potekalo preko katehez o zakramentih krsta, birme in evharistije (Hamman, Korenine naše vere, 79).

6 Zdi se, da Avguštin ni nikoli komentiral pripovedi o postavitvi evharistije pri sinoptikih ali pri Pavlu (1 Kor 11.23-26), komentiral pa je Jezusov govor o kruhu življenja (prim. Jn 6.22-59), verjetno prvič v Kartagini oktobra 417, drugič pa v Hiponu avgusta 419 ali 420 (Sage, "L'Eucaristie dans la pensée de saint Augustin«, 227).

7 V novozavezni dobi je bil krst podeljen po krajši pripravi in izpovedi vere v Kristusa. Kasneje se je čas priprave podaljšal, ne toliko zaradi potrebe po katehezi, torej po doktrinalni pripravi, ampak predvsem zaradi potrebe po dejavni spremembi življenja, saj je bil krst edina priložnost za odpuščanje grehov, zato se je predpostavljalo, da mora kristjan, kar zadeva moralo, živeti popolno. V obdobju pred vladanjem cesarja Konstantina je katehumenat običajno trajal dve do tri leta. 
ki in maloštevilni. Povezani so z obhajanjem evharistične daritve. Pred škofom in novokrščenci je oltar, na katerega sta položena kruh in kelih z vinom. ${ }^{8}$ To bi lahko pomenilo, da je škof imel katehezo med obhajanjem evharistične skrivnosti. ${ }^{9}$

Praznovanje velike noči (tota pashalis solemnitas pravi Avguštin v Govoru 210.9) se je začelo s postnim časom, ko so katehumeni začeli neposredno pripravo na zakramente, ki je dosegla svoj vrhunec v Kristusovem mimohodu (pasha), ko je Božji Sin prišel k nam, da bi spremenil smrt v življenje, in se vrnil k Očetu. V velikonočni noči se v Cerkvi rodijo za novo življenje tisti, ki so bili sprva kandidati, accedentes, ki jih Avguštin imenuje rudes, nato so postali auditores ali catechumeni, potem pa electi ali competentes in, končno, v velikonočni osmini infantes, ${ }^{10}$ saj so doživeli drugo rojstvo od Boga Očeta in matere Cerkve (secunda nativitas ex deo et ecclesia, Sermo 121.4). Oznanjevanje, ki se je v Hiponu v 5. stoletju pričelo na začetku postnega časa ${ }^{11}$ in $\mathrm{za}$ ključilo na nedeljo po veliki noči, je bilo namenjeno prav njim. Pokoro, ki so jo kandidati opravljali pred krstom, so spremljali obredi uvajanja, imenovani skrutiniji. Sledil je sam obred krsta s krstnim potapljanjem, maziljenjem s polaganjem rok in umivanjem nog ter evharistija. Pred krstom so se zvrstile tudi kateheze o veroizpovedi, o Gospodovi molitvi, o krstu in evharistiji. ${ }^{12}$

Ker se o evharistiji pred veliko nočjo ni smelo odkrito govoriti ad populum (disciplina arcani), ${ }^{13}$ Avguštinovi govori na veliki četrtek niso ohranjeni. Imamo pa tri govore o Gospodovem trpljenju in petnajst izrečenih pri velikonočni vigiliji. ${ }^{14}$ Vigiliji je sledilo obhajanje velike noči in zakramentov uvajanja: krst in evharistija. Ob tej priliki so bile kateheze o teh dveh zakramentih,

Po Milanskem ediktu leta 313, ko se je število prosilcev za krst zelo povečalo, pa je postal pomen priprave na krst še bolj poudarjen, sama priprava pa še bolj natančno organizirana (Drobner, Patrologia, 404-406). Običajno in skoraj povsod so krstili za veliko noč, pred krstom pa je ves postni čas potekala intenzivna priprava na prejem zakramentov, medtem ko so same kateheze potekale v velikem tednu (Sage, »L'Eucaristie dans la pensée de saint Augustin«, 222).

8 Boyer, »L'eucharistie selon saint Augustin«, 125.

9 Poque, Introduction, 79.

10 Daniélou, »La catéchèse dans la tradition patristique«, 7-11.

11 Na primer Govori 205-210 so vzpodbude na začetku postnega časa, Govor 211 pa je Avguštin imel sredi posta (Poque, Introduction, 55).

12 Ko so petnajst dni pred veliko nočjo competentes izpovedali vero, je običajno sledil govor $\mathrm{z}$ razlago veroizpovedi. To so Govori 212-15 in O simbolu katehumenom (Poque, Introduction, 59). Gospodovo molitev pa je Avguštin komentiral v Govorih 56-59 (Poque, Introduction, 65). Kristjani so se zbirali za te kateheze v svojih bazilikah sedem dni pred veliko nočjo.

13 Tudi freske $\mathrm{v}$ katakombah, kipi na sarkofagih in zgodnja krščanska ikonografija zaradi t.i. disciplina arcani, to je nekakšnega pravila skrivnosti, tajnosti, ki ga Avguštin večkrat omenja in ki je na splošno v prvih stoletjih krščanstva zaznamovalo pristop k svetim stvarem, niso neposredno predstavljale evharistične daritve (Bruyne, "L'initiation chrétienne«, 67). Postopno uvajanje v krščanske skrivnosti ne gre zamenjati z dolžnostjo tajnosti, ki je zaznamovala prakso misterijskih religij ali gnostičnih sekt. Disciplina arcani je utemeljena pedagoško. Zato so v antiki krstili bodisi med velikonočno bodisi med binkoštno vigilijo. Kateheza pred prejemom zakramentov je trajala celo noč, kljub temu pa so o evharistiji govorili šele po krstu. Novokrščenci so se zjutraj tako spet zbrali in se udeležili druge evharistije ter prisluhnili nauku o tej skrivnosti. Eno redkih besedil patristične literature, ki se ukvarja zgolj z evharistijo, je verjetno tudi zato Ciprijanovo Pismo 63 (Špelič, »Evharistija pri cerkvenih očetih", 66).

14 Poque, Introduction, 72-73; 86. 
ohranjenih jih je dvajset. Ob tej priložnosti Avguštin namreč ni komentiral evangelija, temveč je govoril novokrščenim o Gospodovi večerji. To so t.i. sermones ad populum, ki jih poznamo kot evharistične kateheze. Škof je razlagal darove, ki so jih verniki videli na oltarju, to pomeni, da je govore imel pred posvetilno molitvijo, še bolj običajno pa po njej, in novokrščenim razkrival evharistično resničnost. $\mathrm{V}$ teh govorih Avguštin utemeljuje svojo razlago $\mathrm{s}$ Pavlovim citatom iz 1 Kor 10.17: unus panis, unus corpus, multi sumus, ${ }^{15}$ in poudari paralelizem med pripravo kruha in obredom uvajanja ter poglablja pomen evharistije kot zakramenta edinosti in odrešenja.

Na veliko noč se je začela osmina, med katero se je oznanjevanje stopnjevalo tako v teološkem kot v pedagoškem pogledu, in sicer od Jezusa Kristusa do katoliškosti Cerkve in potrebnosti milosti. V Hiponu je bil to privilegiran teden za kateheze, ki so torej trajale vse do bele nedelje, ko novokrščeni niso bili več infantes, temveč so postali verniki, fideles. Tudi takrat so se zbrali pri jutranji maši in poslušali škofovo katehezo.

\section{Polemično ozadje}

Preden prisluhnemo Avguštinovi besedi o evharistični skrivnosti, moramo odstreti še polemično ozadje, ki je v obdobju manihejstva, donatizma in pelagijanstva zaznamovalo Avguštinovo teološko razmišljanje. V njegovih govorih dejansko odmevajo tudi najtežja in najbolj abstraktna vprašanja, ki so bila odprta v teh polemikah. Avguštinovo oznanjevanje ima namreč poudarjen teološki in doktrinalen značaj. Preko njega posreduje svoja teološka spoznanja in duhovno doumevanje božjih skrivnosti. Oba govora torej odsevata vse značilnosti teološkega oznanjevanja, ki je lastno pastirju v njegovem razmišljanju o življenju in problemih zaupanega mu občestva. ${ }^{16}$

Polemično doktrinalno ozadje donatizma, ki je bil prvotno in primarno religiozne narave, se je prepletalo tudi z družbenimi in kulturnimi značilnostmi, predvsem v Numidiji in Mavretaniji, ki sta se razlikovali od Prokonzulske Afrike. Možno je, da sta v času Dioklecijana in Kostantina zaradi administrativne in davčne reforme donatistična psihologija in duhovnost mučenca bolj odmevali na deželi kot v mestih, tako da je bil donatizem tudi sad partikularizma in nasprotovanja punskega prebivalstva rimski oblasti. ${ }^{17}$ Po drugi strani pa so razlagalci donatizma mnenja, da anarhični oz. nacionalni dejavniki v njem ne opravičujejo njegove opredelitve kot stranke izkori-

15 Avguštin komentira ta odlomek v delu O božjem mestu 10.6. Zakrament evharistije je vir življenja. Pristopiti k evharistiji terja človekovo vero (Ceriotti, L'unità di Cristo, 85). Za uporabo biblije v Avguštinovih govorih glej: Pellegrino, Introduzione generale, XVII-XL.

16 Treba je upoštevati tudi dejstvo, da mistagoške kateheze niso polemični spisi, torej velja upoštevati tudi razliko med poslušalci, ki se pripravljajo na krst, in aktivnimi razpravljalci o doktrinarnih zmotah in shizmah. Glej tudi: Pellegrino, Introduzione generale, XLI-XLII.

17 Frend, »Donatismo«, 1489-1491. 
ščanih in revnih. Shizma, ki je v Avguštinovem času prešla v krivoverstvo, je namreč posledica različnih vzrokov in ne zgolj odpora rimski kolonizaciji. ${ }^{18}$ Prav tako ne gre prezreti tudi družbenega vidika evharistične teologije. Hiponskemu škofu namreč ni bila neznana razslojenost tedanje družbe in Cerkve, ki je izpraševala vest kristjanov, da ne bi padli v protislovje med izpovedjo in delovanjem, med vero in življenjem med obhajanjem evharistije in zaprtostjo srca pred tistimi, ki so udje istega Kristusovega telesa.

Polemike okrog osrednjega vprašanja donatistične shizme o pravi Cerkvi in resničnih delivcih zakramentov ter posledično o njihovi veljavnosti segajo v Afriki daleč nazaj, že v čas Tertulijana, ki je okrog leta 200 po Kr. v delu $O$ krstu trdil, da pri heretikih ni zakramenta, zato je potrebno tiste, ki se spreobrnejo, ponovno krstiti. Tudi Ciprijan je bil leta 251 mnenja, da zakramenti, ki so jih podelili heretiki, niso veljavni. Papež Štefan mu je odgovoril, da je krst, ki ga podeljujejo heretiki, prav tako veljaven, če uporabijo pravilno formulo, kot običajno delajo. Ta polemika torej zoperstavlja duhovništvo, ki ima karizmatično moč posvečevanja, in disciplino oz. pravico vladanja, ki pripada hierarhičnemu duhovništvu.

Drugo vprašanje pa je bilo povezano $\mathrm{z}$ velikim številom kristjanov, ki so v času preganjanja cesarja Decija sredi 3. stoletja iz strahu javno počastili poganska božanstva in tako dejansko odpadli od vere (zato so jih imenovali lapsi), kasneje pa so prosili za ponoven sprejem v Cerkev. Novacijanci so bili proti sprejemu, Ciprijan pa se je zavzel za njihovo ponovno sprejetje, ker je v težkih časih za kristjane razumel, da potrebujejo duhovno moč, ki so jo prejemali po evharistiji. Podobne okoliščine so bile povod za donatistično shizmo pol stoletja kasneje, saj so tudi donatisti menili, da so oni nasledniki prave Cerkve, ki se ni omadeževala v času preganjanja (Dioklecijanovega), in mislili, da je veljavnost zakramentov odvisna od zaslug delivca.

Donatizem je bil predvsem razprava o naravi Cerkve kot družbe in o njenem razmerju do sveta. Že Tertulijan je poudarjal potrebo po svetosti Cerkve. Tudi Ciprijan je trdil, da more odpuščati grehe le Cerkev, hkrati pa tudi, da noben duhovnik $\mathrm{v}$ stanju smrtnega greha ne more veljavno podeljevati zakramentov (Pismo 67.4). Poleg tega, kot smo že rekli, po mnenju Ciprijana zunaj Cerkve ne more biti veljavnega zakramenta, torej ga je potrebno ponovno podeliti. ${ }^{19}$ Ciprijan je o vlogi Cerkve razmišljal v delu O edinosti Cerkve 6, kjer trdi, da ne more imeti Boga za očeta, kdor nima Cerkve za mater (habere non potest Deum patrem qui Ecclesiam non habet matrem). Donatisti so izpeljali Tertulijanove in Ciprijanove misli do skrajnosti in zagovarjali absolutno čistost svete in brezmadežne Cerkve.

Od afriškega radikalizma, ki je razdeljeval ljudi znotraj in zunaj Cerkve, se je sredi 4. stoletja oddaljil Optat Milevski. Odprl je namreč možnost, da 
imajo zakramenti tudi posvečevalno moč, kajti zakramentov ne podeljuje Cerkev, ne delivec zakramentov, temveč sam Bog. Tako prvič naletimo na trditev, da so zakramenti sveti ne zaradi delivca, temveč sami po sebi (sacramenta per se sancta, non per homines). Dolga pot je bila potrebna, da znotraj nadnaravne odrešenjske ojkonomije Cerkev ni dajala več prednosti subjektivnemu, osebnemu dejavniku.

Avguštin je še bolj razvil to razumevanje in pojasnil, da so zakramenti sveti ne zaradi delivcev ali sami po sebi, temveč zaradi Kristusa, ki jih je postavil. Zakramenti namreč pripadajo Kristusu in Cerkvi. Avguštin je torej dokončno in pravilno razvil nauk o zakramentih in trdil, da je krst (prav tako tudi sveti red) veljaven tudi izven Cerkve, učinkovit pa je le v njej. Gre torej za dve dejstvi, ki se ju ne sme istovetiti, namreč, za resničnost zakramenta in za njegovo učinkovitost (O krstu 4,17,24; 6,1,1). Kristus je glavni delivec zakramenta krsta, ki človeka zapečati z neizbrisnim znamenjem (character) tudi izven Cerkve, toda, če je kdo brez ljubezni in ni združen z drugimi udi Cerkve, je brez krstne milosti.

$\mathrm{V}$ pelagijanskem sporu, ${ }^{20} \mathrm{v}$ katerega se po donatističnem kar preliva Avguštinovo doktrinalno iskanje, moramo najprej izpostaviti dejstvo, da je v tej polemiki hiponski škof razvijal teologijo odrešenja. Šlo je za vprašanje razmerja med božjo milostjo in človeško svobodo, za vprašanje izvirnega greha in opravičenja, utemeljenega na Kristusovi daritvi in ne na človekovih delih. Pelagij se je rodil sredi 4. stoletja. Predlagal je ideal svetosti, ki ga človek doseže predvsem preko svobodne volje, popolnoma usmerjene k Bogu. Govoril je seveda tudi o milosti, ki je poudarjena v Pavlovih pismih, toda milost je zanj preprosto človeška narava, taka, kot jo je ustvaril Bog.

Takšno enačenje narave in milosti je izviralo iz Pelagijevega zanikanja dejstva izvirnega greha. Po njegovem mnenju je bilo namreč nemogoče, da bi bila tako popolno ustvarjena duša človeka od začetka obremenjena s tako velikim grehom. Krst je pri odraslem podeljen v odpuščanje grehov, ki jih je le-ta do tedaj storil. Pri otroku pa nikakor ni podeljen v odpuščanje grehov, temveč kot vrata v božje kraljestvo, ker otrok zaradi nepriznavanja izvirnega greha ni omadeževan $z$ njim, osebnih grehov pa še ni mogel storiti. Pelagij je torej postavil pod vprašaj dejstvo, da so v Adamu resnično vsi grešili (Rim 5.12), zato je prepričan, da otroci ne potrebujejo krsta za zveličanje. Zato je dojenčkom pripisal popolno nedolžnost, otrokom, preminulim brez krsta, pa je obljubljal vstop v večno življenje, saj Bog ne more kaznovati s peklom tistih, ki niso osebno grešili. Pretirano je poudarjal človekovo sposobnost svobodne izbire dobrega ali zla, izpolnjevanja božje postave na podlagi lastnih moči. Avguštin je svoj odgovor Pelagiju in njegovim pristašem (Celestiju in Julijanu) oblikoval na podlagi Svetega pisma in izročila Cerkve. Kristus je po njegovem mnenju velik zdravnik tudi za otroke, ker jih rešuje od izvirnega gre-

20 Za poglobitev: Grossi, »Pelagio - Pelagiani - Pelagianesimo«, 3996-4005. 
ha, ki so ga deležni ne po lastni izbiri, ampak kot del človeštva, in sicer jih rešuje po krstu. Pelagija in pelagijanstvo je na Zahodu dokončno obsodil koncil v Kartagini leta 418, na Vzhodu pa efeški koncil leta 431. ${ }^{21}$

\section{Teološko ozadje}

Teologi, in ne samo oni, so se veliko ukvarjali z Avguštinovim naukom o zakramentih. On sam je iz pastoralnih in doktrinalnih razlogov veliko govoril in pisal o njih, zlasti o krstu, spovedi, evharistiji in zakonu. ${ }^{22}$ Zgoščeno temo predstavi predvsem v polemiki z donatisti, in sicer v delu $O \mathrm{krstu}$.

V reševanju teoloških sporov, ki so zadevali zakramente, je bil Avguštinov prispevek odločilen, predvsem ko je šlo za pojasnilo, da so zakramenti veljavni ne glede na subjektivne zasluge delivca, učinkoviti pa so pod določenimi pogoji. Avguštin je tako razlikoval med zakramentom in njegovo učinkovitostjo, tj. med resničnostjo (res sacramenti), ${ }^{23}$ močjo zakramenta (virtus sacramenti) in učinkovitostjo zakramenta (fructus sacramenti). Duhovna resničnost, ki je sad vsakega zakramenta, je odrešenje, ljubezen. Moč zakramenta je to, kar vsak zakrament dela v človeku in v Cerkvi, njegova zmožnost - sposobnost odrešenja. To pomeni, da zakrament sam po sebi vedno prinaša odrešenje, vendar lahko ostane neučinkovit, če v človeku ni pravega notranjega razpoloženja.

Hiponski škof izhaja iz splošne opredelitve zakramenta kot svetega znamenja, vidnega in stvarnega, ki pokaže na duhovno resničnost in ima duhovne učinke. ${ }^{24}$ Odrešenje, ki izvira iz Kristusove velike noči je res, zunanji obred je sacramentum, ki ima dva sestavna dela: materialni in besedni (res in verba), kar pomeni, da beseda, dodana materiji, udejanji zakrament. Zunanji obred je torej signum sacrum, ker pokaže na odrešenje, ki ga vsebuje. Zakramenti so signa naturalia, torej je sama snov, materija tista, ki daje pomen, določen po božji volji: voda, ogenj, olje, kruh, vino itd. ${ }^{25}$ Vse ustvarjeno pripada ali resničnosti (res) ali znamenju (signum). Znotraj širokega polja znamenj so zakramenti sveta znamenja, ki so $\mathrm{v}$ razmerju podobnosti z resničnostjo (res). Toda za Avguština res ni nikoli zgolj virtus sacramenti, saj se zakramenti nanašajo na Kristusa in na odrešenjsko ojkonomijo.

Avguštinovega evharističnega nauka ni lahko opredeliti. Njegovi spisi o evharistiji so številni, vsebujejo definicije, ki so na videz zelo jasne, v resnici

21 Brown, La vie de saint Augustin, 447-64.

22 Trapè, »S. Agostino «, 423.

23 Bistvo zakramenta evharistije je dejanje ljubezni, ki ga človek izraža Bogu, torej Kristusu kot Bogu, in ga izraža po Kristusu kot človeku in s Cerkvijo, njegovim mističnim telesom, dokler ne bo v polnosti dopolnjena ta skrivnost skupnosti (Folliet, »Une définition augustinienne«, 527).

24 Marafioti, »Eucaristia e Chiesa«, 104.

25 "Simbolika dejanj in obredov vode, olja, lomljenega kruha, vina naj bi pomagala odkriti resničnost, ki je očem nevidna, odkrita pa je veri: krščansko skrivnost « (Hamman, Korenine naše vere, 79). 
pa niso vedno lahko združljive. ${ }^{26}$ Razumevanje poleg tega, da je sama tema zahtevna, otežuje tudi veliko alegoričnih razlag, ki jih Avguštin uporabi kot sredstvo za prehajanje od znamenja k resničnosti (signum - res), od konkretnega dejstva k duhovnemu sporočilu istega dejstva. ${ }^{27}$ Evharistična skrivnost vključuje tri vidike: je čisti simbol (sacramentum), to je, da kruh in vino, potem ko so izrečene posvetilne besede, pomenita in vsebujeta Kristusovo telo in kri; je resničnost-simbol (res in sacramentum), to pomeni, da sta resničnost telesa in krvi, ki sta sad obreda, hkrati tudi simbol, ker izražata Cerkev kot Kristusovo telo; in čista resničnost (res) kot Kristusovo telo, torej milost združenosti s Kristusom, ki ustvarja edinost. Učinki evharistične skrivnosti so osebna incorporatio, občestvena concorporatio in vstajenje. ${ }^{28}$

Avguštin ne razpravlja o resnični Kristusovi navzočnosti pod evharističnima podobama, saj je o tem prepričan. Nobenega dvoma ni bilo o tem, zato tudi ni bilo nobenega razloga, da bi jo zagovarjal. V Avguštinovih spisih velikokrat opazimo eksplicitno povezavo med resničnostjo učlovečenja in evharistično skrivnostjo. V trpljenju je Kristus daroval to, kar je v učlovečenju prevzel od človeka, se pravi telo in kri, človeško naravo. To njegovo telo je bilo na križu darovano in s sulico prebodeno za odpuščanje grehov. Zato pravi: „Ko se spomnite te milosti in ko uresničujete svoje odrešenje (ki ga Bog sam izvršuje v vas), se s strahom in trepetom približate k udeležbi pri tem oltarju. V kruhu prepoznate isto telo, ki je viselo na križu, in v kelihu isto kri, ki je pritekla iz njegove strani." (Govor 228/B.2) ${ }^{29}$ Ker je za Avguština evharistija znamenje (signum) Kristusove navzočnosti, lahko reče, da je po evharistiji Kristus zelo blizu vernikom, ki ga morejo prepoznati v znamenju razlomljenega kruha. Prepoznati se da v lomljenju kruha, »zaradi nas, ki ga ne bomo videli v človeški podobi, temveč bomo jedli njegovo meso. /.../ Gospodova odsotnost ni odsotnost. Veruj, in tisti, ki ga ne vidiš, je s teboj.« (Govor $235.3)^{30}$

Torej so v Avguštinovih spisih res, signum in sacramentum vselej prepleteni. Avtorji običajno poudarjajo liturgični realizem Ambroža, ki opredeljuje zakrament s tem, kar je sam v sebi, v nasprotju s simbolizmom Avguština, ki naj bi ga opredelil v razmerju s tistim, ki ga prejme. Toda pravilen ključ interpretacije Avguštinovega nauka je njegovo teološko razumevanje evharistije. ${ }^{31}$

\footnotetext{
26 Boyer, "L'eucharistie selon saint Augustin«, 125.

27 Bareille, »Eucharistie d'après les Pères«, 1174.

28 Po včlenjenju v Kristusovo telo kristjan prejme vse darove: božje posinovljenje, občestvo Svete Trojice, edinost s Kristusovim telesom, ki je Cerkev, poroštvo večnega življenja in vstajenje mesa. V moči včlenjenja lahko kristjan Kristusu v daritev daruje samega sebe (Ratzinger, La comunione nella Chiesa, 170-75).

29 "Huius gratiae memores, vestram ipsorum salutem operantes, quoniam Deus est qui operatur in vobis, cum timore et tremore ad participationem huius altaris accedite" (Sermo 228/B,2).

30 »Noluit agnosci, nisi ibi, propter nos, qui non eum visuri eramus in carne, et tamen manducaturi eius carnem. /.../ Absentia Domini non est absentia. Habeto fidem, et tecum est quem non vides« (Sermo 235.3).

31 Grossi, »L’Eucaristia in S. Agostino«, 263.
} 
Kristus je sicer enkrat za vselej daroval samega sebe, vendar se pri liturgični skrivnosti ne samo na veliko noč, marveč vsak dan znova, daruje za vernike. ${ }^{32}$ Daruje se pa zares. "Kajti če zakramenti ne bi bili v nobenem razmerju podobnosti z resničnostmi, katerih znamenja so, sploh ne bi bili zakramenti. Iz tega razmerja podobnosti dejansko zajemajo tudi ime teh resničnosti. Tako je zakrament Kristusovega telesa na nek način Kristusovo telo, zakrament Kristusove krvi pa je sama Kristusova kri.« (Pismo 98.9) ${ }^{33}$ Torej zakrament uresničuje Kristusovo navzočnost na poseben način: Kristus je namreč navzoč in deluje po besedi in po evharistiji. Kruh in vino sta zakrament, to je znamenje, ki v polnosti uresničuje navzočnost Kristusovega telesa in krvi. Tako pravi: »Predragi, to, kar vidite na Gospodovi mizi, sta kruh in vino, vendar ta kruh in to vino po sredništvu besede postaneta telo in kri Besede. /.../ Po besedi sta navzoča Kristusovo telo in kri. /.../ Če namreč izvzameš besedo, sta kruh in vino; če dodaš besedo, postane zakrament. Zato rečete 'Amen'. Reči 'Amen,' pomeni podpisati. 'Amen' namreč v latinščini pomeni: Res je.« (Govor $229.1 ; 3)^{34}$

Teološko ozadje Avguštinovih evharističnih katehez in njegov doprinos k zakramentalni teologiji nas obvezno pripelje do njegovega pojmovanja Cerkve in njegovega odgovora na vprašanje o prisotnosti grešnikov v njej. Avguštin je v protidonatističnih spisih ${ }^{35}$ in v delu $O$ božjem mestu razvil pojmovanje Cerkve kot občestva vernikov, ki je zgrajeno na temelju apostolov (communio sacramentorum) kot občestvu pravičnih, ki roma po zemlji od Abela do konca časov (communio iustorum) in kot občestva predestiniranih, ki žive v nesmrtni blaženosti (communio sanctorum). Prvo občestvo združi dobre in slabe pod vodstvom škofov, ki delujejo v skladu $\mathrm{z}$ določili koncilov in rimskega škofa. O communio sacramentorum lahko govorimo torej le v Cerkvi, ne glede na to, da so zakramenti veljavni tudi izven Cerkve, ker zunaj nje niso

32 Res sacramenti je v primeru evharistije resnična Kristusova daritev na Kalvariji in se nanaša na navzočnost Svetega Duha v evharistiji ter na edinost udov, tj. na resničnost božjega mesta, kjer vladata mir in bratska povezanost (Sage, »L'Eucaristie dans la pensée de saint Augustin«, 232).

33 "Si enim sacramenta quamdam similitudinem earum rerum quarum sacramenta sunt, non haberent, omnino sacramenta non essent. Ex hac autem similitudine plerumque etiam ipsarum rerum nomina accipiunt. Sicut ergo secundum quemdam modum sacramentum corporis Christi corpus Christi est, sacramentum sanguinis Christi sanguis Christi est« (Epistola 98.9). $\mathrm{V}$ 4. stoletju Ambrož in Avguštin uporabljata načelo podobnosti v zvezi z zakramenti (Grossi, L'Eucaristia, corpo della Chiesa, 9). Zakramenti morajo namreč imeti kakšno podobnost s stvarmi, katerih znamenje so (Van der Lof, „Eucaristie et présence réelle«, 296).

34 "Hoc quod videtis, carissimi, in mensa Domini, panis est et vinum; sed iste panis et hoc vinum accedente verbo fit corpus et sanguis Verbi. ...ut accedente verbo fiat corpus et sanguis Christi. Nam tolle verbum, panis est et vinum: adde verbum, et iam aliud est. Et ipsum aliud, quid est? Corpus Christi, et sanguis Christi. Tolle ergo verbum, panis est et vinum; adde verbum, et fiet sacramentum. Ad hoc dicitis: Amen. Amen dicere, subscribere est. Amen latine interpretatur "verum«" (Sermo 229.1;3).

35 Avguštinovi protidonatistični spisi odsevajo splošno sprejeta prepričanja afriških kristjanov, zlasti pojem Cerkve kot skupine, povsem ločene od družbe in edine nosilke odrešujočih zakramentov (Brown, La vie de saint Augustin, 292). Za poglobitev vprašanja reševanja donatistične shizme v letih 409-11, ko so se škofje zbrali na sinodi v Kartagini, glej: Brown, La vie de saint Augustin, 433-40. 
pa učinkoviti. Drugo občestvo se je oblikovalo že pred Kristusom, vendar ne brez njega, in teži k eshatonu. Tretje je občestvo svetih, ki so že dosegli nebeško slavo. ${ }^{36}$

Sveta Cerkev so torej vsi krščeni. V communio sacramentorum so tako vključeni tudi grešniki, ki ob koncu časov ne bodo mogli imeti deleža v communio sanctorum. Avguštin rad uporablja Pavlovo prispodobo (similitudo) telesa, ko govori o Cerkvi (prim. 1 Kor 12.27). ${ }^{37}$ Kristus je glava, kristjani pa udje, vendar poudarja, da so udje Kristusovo telo ne posamezno, temveč vsi skupaj, v medsebojni edinosti. ${ }^{38}$ Če je Kristus glava, Cerkev pa njegovo telo, med njima obstaja tesnejše razmerje, kot je odnos med gospodarjem in služabniki. Med njima je vez ljubezni, edinosti in miru, ${ }^{39}$ ne glede na to, da v telesu niso zdravi vsi udje.

Zato je razumljivo, da ima Cerkev dve razsežnosti: kot Kristusovo telo je nevidno občestvo, združeno v izpovedi vere v Sveto Trojico. Cerkev kot zgodovinska resničnost, vidno občestvo, pa je združena okrog škofa. Pomembno je poudariti, da ta dvojnost ne prizadene edinosti Cerkve. Takšno dvojnost Avguštin zaznava tudi na področju spoznavanja, ko govori o species in intellectus. Avguštin gleda na vidno stvarnost v Platonovi perspektivi kot na realni simbol nevidne stvarnosti. ${ }^{\circ}$ Ontologija stvarnosti se nanaša na poslednji temelj vsega ustvarjenega, ki je v Bogu. ${ }^{41}$ Prav zaradi omenjene postavitve lahko hiponski škof razlikuje med zakramentalnim, zgodovinskim in nebeškim občestvom, ki je pomembno tudi za reševanje različnih sporov, shizm in krivoverstev. Poudariti velja, da Avguštinovi ekleziološki pojmi izražajo njegov kristocentričen in trinitaričen pristop, saj je Sveta Trojica model, počelo in zadnji smisel Cerkve, kar je razvidno iz poudarka na vlogi Kristusa in Svetega Duha kot duše Cerkve. ${ }^{42}$

Avguštin torej poglablja razumevanje narave Cerkve kot zgodovinske in hkrati eshatološke resničnosti, kot hierarhičnega in mističnega telesa, kot vidne in nevidne resničnosti. To je totum Christi corpus. Kakor Hilarij in Leon Veliki tudi Avguštin govori o skrivnosti ali zakramentu Kristusovega telesa. $\mathrm{V}$ njem je povezanost med verniki ne le fizična in duhovna, temveč tudi mistična. Kristjani so duhovni udje Cerkve, mistični udje tega telesa, katerega glava je Kristus. Corpus mysticum je za Avguština tisto občestvo svetih, ki ga imenuje mistična Cerkev, ki ga ne smemo istovetiti z občestvom romarjev na tej zemlji v večno domovino (Govor 252.7). Mistična Cerkev je zanj mistično telo, skrivnostno telo. ${ }^{43}$

36 Trapè, »Agostino d'Ippona«, 155.

37 Glej na primer Govor 341.11 .

38 Sage, "L'Eucaristie dans la pensée de saint Augustin«, 224.

39 Binom pax in unitas je zelo poudarjen pri Ciprijanu (Pellegrino, Introduzione generale, XLVII).

40 Prav tako je zakrament vedno povezan z nevidno resničnostjo. Sveti Duh nevidno deluje in povezuje res in sacramentum (Van der Lof, „Eucaristie et présence réelle«, 297-99).

41 Panizzolo, "Gli elementi essenziali della communio«, 267.

42 Pellegrino, Introduzione generale, XLVII-XLVIII.

43 De Lubac, Corpus Mysticum, 16-18. 
Evharistija je pri Avguštinu tesno povezana s Cerkvijo, in sicer v istem razmerju kot vzrok-učinek, sredstvo-cilj, znamenje-resničnost. Prehod od zakramenta k moči zakramenta (virtus) oz. od vidnega (species visibilis) k resničnosti (res ipsa) se pri hiponskem škofu neposredno uresničuje ne kot evharistija, ampak kot Cerkev. Uživati Kristusovo telo in kri namreč pomeni včlenitev v Cerkev, v Kristusovo mistično telo. Zato je evharistija sacramentum pietatis, signum unitatis, vinculum caritatis (In Ioa. evangelium 26.13), torej zakrament dobrotljivosti, znamenje edinosti, vez ljubezni. ${ }^{44}$

Avguštinovo zakramentalno teologijo torej zaznamujejo tri razsežnosti: kristološka, ekleziološka in pnevmatološko-duhovna, in sicer zato, ker se vsak zakrament najprej nanaša na Kristusa, na njegovo osebo in delovanje v njegovem srečevanju s slehernim človekom. Potem se zakrament poveže z delovanjem Cerkve, v kateri je podeljen, kajti zakramenti človeka včlenijo vanjo in jo tako oblikujejo. Končno po zakramentih deluje Sveti Duh, ki oblikuje notranje življenje kristjana, mu daje rast v ljubezni in tako slehernega povezuje s Kristusom in Cerkvijo. V evharistiji so te razsežnosti kristalno razvidne. V njej se uresničuje tudi občestvo med Kristusom in Cerkvijo ter izmenjava med Srednikom in verniki, saj je v resnici edini zakrament Cerkve Učlovečena Beseda. ${ }^{45}$

\section{EVHARISTIJA "MYSTERIUM UNITATIS « V GOVORU 272}

Kot smo že omenili, je mistagoški Govor 272 Avguštin namenil neofitom za binkošti ali za veliko noč, da bi predstavil zakrament evharistije. V njem govori o Svetemu Duhu v Cerkvi, in sicer mu priznava podobno vlogo, kot jo ima duša v telesu. To pomeni, da po antropološki analogiji Cerkev potrebuje Kristusovega Duha, da bi bila njegovo živo telo. ${ }^{46}$ Govor bomo prevajali in analizirali v štirih sklopih: binom signum - res; binom fides - ratio; binom Kristusovo telo - mistično telo Cerkve; binom virtus - fructus sacramenti. Iz besedila lahko sklepamo, da je v tem govoru ekleziološki vidik evharistije kot skrivnosti edinosti posebno izpostavljen.

44 Formula sacramentum caritatis je navzoča v Avguštinovih spisih, vendar v zvezi z Gospodovim trpljenjem: »Ad sacramentum caritatis ostendendum, minus enim quam inter duos caritas esse non potest. Erat autem ille non necessitate debiti propter peccatum suum, sed ad solvenda nostra peccata caritate passurus«(Quaest. Evangel. 1.27). Hiponski škof uporablja znani izraz vinculum caritatis, ko komentira $J n 5.51 \mathrm{v}$ evharističnem smislu: »O sacramentum pietatis! O signum unitatis! O vinculum caritatis! Qui vult vivere, habet ubi vivat, habet unde vivat. Accedat, credat, incorporetur, ut vivificetur« (In Ioa. Evangelium 26). Pío de Luis ta znani Avguštinov vzklik razlaga v trinitaričnem smislu (»La Eucaristía«, 48).

45 Za poglobitev teme »Kristus - zakrament Boga« in »Cerkev - zakrament Kristusa«: Turnšek, "Zakramenti«, 204-206.

46 dell'Osso, »Il Christus totus«, 341. 


\section{Binom signum - res}

Avguštin takoj na začetku nagovori novokrščence tako, da pokaže na že pripravljene, vendar še ne posvečene darove. Pred posvetitvijo je kruh namenjen za hrano, ne za obredno dejanje, saj sta kruh in vino, kakor druge prvine, ki se uporabljajo pri zakramentih, naravni sestavini. Njuna priprava pa je primerna za to, da na simbolen način predstavita to, kar bo učinek zakramenta. ${ }^{47}$

Hoc quod videtis in altari Dei, etiam transacta nocte vidistis: sed quid esset, quid sibi vellet, quam magnae rei sacramentum contineret, nondum audistis. Quod ergo videtis, panis est et calix; quod vobis etiam oculi vestri renuntiant: quod autem fides vestra postulat instruenda, panis est corpus Christi, calix sanguis Christi.

To, kar vidite na božjem oltarju, ste videli tudi sinoči. Toda niste še slišali, kaj je to, kaj to pomeni, znamenje kako velike stvarnosti je. To, kar vidite, sta kruh in kelih. To vam zagotavljajo tudi vaše oči, toda po veri, ki se mora v vas še oblikovati, je kruh Kristusovo telo, kelih pa je Kristusova kri.

Iz besedila je razvidno, da je za Avguština zakrament sveto znamenje, vidno in stvarno, ki prikliče duhovno resničnost. V zakramentu sta navzoča dva dejavnika, stvarni in besedni. ${ }^{48}$ Ko duhovnik izgovori besede posvetitve, kruh postane telo, vino pa kri. Zgodi se veliko sprememba, ki je bila napovedana. Naravne sestavine so postale zakrament, to je skrivnost, skrita v vidnem znamenju.

Avguštinov evharistični nauk razlagalci opredelijo kot zakramentalen, kajti beseda sacramentum ${ }^{49}$ vsebuje hkrati besedo signum in res. Kruh in vino sta znamenje (signum), ker po veri v njiju vidimo Kristusovo telo in kri (res). Še več, evharistični zakrament vsebuje močan ekleziološki vidik. V Avguštinovi evharistični teologiji moramo tako videti zakramentalni realizem in dinamizem. Realizem se nanaša na to, kar evharistija resnično je, se pravi na Kristusovo telo; dinamizem pa na to, kar se po evharistiji izvršuje - spreminja vernike v Kristusovo telo, ki je Cerkev. ${ }^{5}$ Avguštin izhaja iz vere v realno Kristusovo navzočnost v evharistiji (zakramentalni realizem) in se sprašuje, kaj evharistija povzroča $\mathrm{v}$ posamezniku in v občestvu (zakramentalni dina-

47 Boyer, »L'eucharistie selon saint Augustin«, 126.

48 Marafioti, „Eucaristia e Chiesa«, 104.

$49 \mathrm{~V}$ prvih spisih Avguštin za označitev evharistije uporablja besedo signum, similitudo, figura, imago. Po škofovskem posvečenju pa vedno uporablja besedo sacramentum, čeprav v Presojah ni zaznal te jezikovne spremembe, ki jo je mogoče pripisati razpravi zoper manihejstvo (Sage, "L'Eucaristie dans la pensée de saint Augustin«, 216-17).

50 Povezava med evharistijo in edinostjo Cerkve se je v teku stoletij vedno bolj kristalizirala. Od Nauka dvanajstih apostolov oz. Didahe naprej viri poudarjajo enakost med udeleženci, ki se med seboj opredelijo kot bratje. 
mizem). Po udeležbi pri Kristusovem telesu posameznik doseže nesmrtnost in večno življenje, občestvo pa postane Cerkev. ${ }^{51}$

\section{Binom fides - ratio}

Breviter quidem hoc dictum est, quod fidei forte sufficiat: sed fides instructionem desiderat. Dicit enim propheta: Nisi credideritis, non intellegetis. Potestis enim modo dicere mihi: Praecepisti ut credamus, expone ut intellegamus. Potest enim in animo cuiusquam cogitatio talis suboriri: Dominus noster Iesus Christus, novimus unde acceperit carnem; de virgine Maria. Infans lactatus est, nutritus est, crevit, ad iuvenilem aetatem perductus est, a Iudaeis persecutionem passus est, ligno suspensus est, in ligno interfectus est, de ligno depositus est, sepultus est, tertia die resurrexit, quo die voluit, in coelum ascendit; illuc levavit corpus suum; inde est venturus ut iudicet vivos et mortuos; ibi est modo sedens ad dexteram Patris: quomodo est panis corpus eius? et calix, vel quod habet calix, quomodo est sanguis eius? Ista, fratres, ideo dicuntur Sacramenta, quia in eis aliud videtur, aliud intellegitur. Quod videtur, speciem habet corporalem, quod intellegitur, fructum habet spiritalem.

To, kar je torej rečeno na kratko, morda veri tudi zadošča, ampak vera želi poduk. Prerok namreč pravi: Če ne boste verovali, ne boste razumeli. Vi bi mi lahko dejansko rekli: »Naročil si nam, naj verujemo, razloži pa, da bomo razumeli.« V srcu koga bi lahko nastalo tako razmišljanje: vemo, od kod je naš Gospod Jezus Kristus dobil telo: iz Device Marije. Kot otroka ga je dojila in hranila. Rasel je, preživel mladost, trpel preganjanje s strani Judov, visel na križu, umrl na križu, s katerega so ga sneli, bil je položen v grob in tretji dan vstal, na dan, ko je hotel, je šel v nebesa in tja dvignil svoje telo. On bo prišel sodit žive in mrtve. Do takrat sedi na desnici Očetovi: torej, kako more biti ta kruh njegovo telo? In kelih, to, kar je v njem, kako more biti njegova kri? Bratje, te stvari se imenujejo zakramenti, kajti v njih vidiš eno resničnost, razumeš pa drugo. To, kar vidimo, ima materialni videz, to, kar umevamo, pa ima duhovni učinek.

Na vprašanje, ki si ga lahko postavi razum, kako moreta biti kruh in vino Kristusovo telo in njegova kri, Avguštin ne odgovori tako natančno, kot kasneje zasledimo pri sv. Tomažu Akvinskem, temveč z delitvijo aliud videtur, aliud intelligitur. ${ }^{2}$ Morda ga je ustavila disciplina arcani, morda enostavno njegovo prepričanje, da naj se verniki rajši zadovoljijo z odgovorom čiste vere. Na zemlji verujemo, v nebesih pa bomo videli. ${ }^{53}$

51 Marafioti, »Eucaristia e Chiesa«, 105-106; 116.

52 Van der Lof, "Eucaristie et présence réelle«, 300.

53 Boyer, »L'eucharistie selon saint Augustin«, 135. 
Avguštin je prepričan, da samo vera človeku poda pravilno razumevanje Jezusovega nauka. Da bi bil razum razsvetljen in da bi razumel, je potrebno najprej z vero sprejeti Kristusa, torej verovati vanj, da bi ga poznali. Vera je gotovo nezaslužen dar, milost. Milost je pot k veri in vera je pot k razumevanju. Vera je za Avguština potrebna za tri namene: da bi razumeli Jezusove besede; da bi v kruhu in vinu prepoznali Kristusovo telo in kri; da bi sprejeli s čistim srcem in na pravi način Kristusovo telo.

Avguštin je sledil programu credo, ut intelligam, in intelligam, ut credam (Serm. 43.9), saj ni črpal le iz razuma, temveč predvsem iz tesne povezanosti z Učiteljem v molitvi in po milosti Svetega Duha. ${ }^{54} \mathrm{~V}$ postavljenem vprašanju vsekakor odmevata Avguštinovo teološko poglabljanje kristologije in zagovarjanje pravovernosti zoper manihejca Favsta in njegov dualizem, ${ }^{55}$ pri katerem se na tem mestu ne moremo ustavljati.

\section{Kristusovo telo - mistično telo Cerkve}

Že pred Avguštinom so očetje primerjali edinost Kristusovega telesa, ki je Cerkev, s podobo kruha in vina. O tem govori tudi hiponski škof sam, ko v Razlagi Janezovega evangelija 26.6.17 omenja Ciprijana in njegovi Pismi 63 in $76 .{ }^{56}$ Gre za Pavlov evharistični simbolizem tesne povezanosti udov v enem telesu, ${ }^{57}$ ki poudarja notranjo vez med Kristusom in Cerkvijo. Zanimivo je, da ta zelo stara formula, ki se uporablja še danes (Corpus Christi-Amen), ni le privolitev, temveč trden sklep ostati v Kristusu, pripadati njemu in njegovemu telesu. Tukaj Avguštin razvija nekakšen ekleziološki simbolizem, tako da je način priprave kruha zanj podoba katehumenove priprave na prejem evharistije. Tako je zakramentalno izkustvo vedno povezano z življenjem Cerkve. $\mathrm{V}$ njej se prepoznajo vidni sadovi zakramenta, kadar je zakrament učinkovito prejet. Gre za enost in mir..$^{8}$

Corpus ergo Christi si vis intellegere, Apostolum audi dicentem fidelibus: Vos autem estis corpus Christi, et membra. Si ergo vos estis corpus Christi et membra, mysterium vestrum in mensa Dominica positum est: mysterium vestrum accipitis. Ad id quod estis, Amen respondetis, et respondendo subscribitis. Audis enim, Corpus Christi; et respondes, Amen. Esto membrum corporis Christi, ut verum sit Amen. Quare ergo in pane? Nihil hic de nostro afferamus, ipsum Apostolum identidem audiamus, qui cum de isto Sacramento loqueretur, ait: Unus panis, unum corpus multi sumus: intellegite et gaudete; unitas, veritas, pietas, caritas. Unus panis: quis est iste

\footnotetext{
54 Di Nola, La dottrina eucaristica, 18.

55 Van der Lof, „Eucaristie et présence réelle«, 304.

56 Boyer, »L'eucharistie selon saint Augustin«, 126.

57 Pasquato, »Eucaristia e Chiesa«, 48-52.

58 dell'Osso, »Il Christus totus«, 343 .
} 
unus panis? Unum corpus multi. Recolite quia panis non fit de uno grano, sed de multis. Quando exorcizabamini, quasi molebamini. Quando baptizati estis, quasi conspersi estis. Quando Spiritus Sancti ignem accepistis, quasi cocti estis. Estote quod videtis, et accipite quod estis. Hoc Apostolus de pane dixit. Iam de calice quid intellegeremus, etiam non dictum, satis ostendit. Sicut enim ut sit species visibilis panis, multa grana in unum consperguntur, tamquam illud fiat, quod de fidelibus ait Scriptura Sancta: Erat illis anima una, et cor unum in Deum: sic et de vino. Fratres, recolite unde fit vinum. Grana multa pendent ad botrum, sed liquor granorum in unitate confunditur. Ita et Dominus Christus nos significavit nos ad se pertinere voluit, mysterium pacis et unitatis nostrae in sua mensa consecravit.

Če želiš doumeti Kristusovo telo, poslušaj apostola, ki vernikom pravi: »Vi ste Kristusovo telo in njegovi udje. ${ }^{59}$ Če ste torej vi Kristusovo telo, je na Gospodovo mizo položena vaša skrivnost: prejemate svojo skrivnost. Temu, kar ste, odgovorite: »Amen, « in tako z odgovorom to podpišete. Ko slišiš: "Kristusovo telo, «ti odgovoriš, "Amen«. Bodi ud Kristusovega telesa, da bi bil tvoj Amen resničen. Zakaj v kruhu? Naj nič ne prinesemo iz svojega, temveč vedno poslušajmo apostola, ki pravi: »Ker je en kruh, smo mi, ki nas je veliko, eno telo, ker smo vsi deležni enega kruha. $"{ }^{60}$ Umejte in se radujte; enost, resnica, svetost, ljubezen. »En kruh«: kdo je ta kruh? »Mi, ki nas je veliko, smo eno telo.« Spomnite se, da kruh ni sestavljen iz enega zrna, temveč iz mnogih. Ko so nad vami izvrševali eksorcizme, ste bili, kakor bi vas mleli. Ko ste bili krščeni, ste bili kakor bi vas zamesili. Ko ste prejeli ogenj Svetega Duha, ste bili kakor pečeni. Bodite, kar vidite, in prejmite, kar ste. To je apostol povedal o kruhu. To, kar moramo razumeti glede keliha, čeprav ni bilo nič izrečeno, je dovolj pokazal. Tako kot so namreč, zato da bi prišlo do vidne oblike kruha, zamešena mnoga zrna v eno, tako se zgodi to, kar pravi Sveto pismo o vernikih: »Imeli so eno dušo in eno srce v Bogu, « tako tudi z vinom. Bratje, pomislite, od kod vino. Mnoge jagode so vezane na trto, vendar sok jagod postane eno. Tako nas je tudi Kristus Gospod hotel na ta način simbolizirati in želi, da njemu pripadamo, ter je posvetil skrivnost našega miru in edinosti na svoji mizi.

Spremenjenje Cerkve v Kristusovo telo je za Avguština velik čudež. Novokrščenci začenjajo prejemati to, kar so začeli biti. Kruh izraža enost mističnega telesa, ki je Cerkev. ${ }^{61}$ Mysterium vestrum accipistis ... Mysterium pacis et unitatis nostrae in sua mensa consecravit: Avguštin uporablja besedo mysterium, ker se nanaša na resničnost, ki je skrita v kruhu in vinu, v zakramentu Kristusovega telesa in krvi. ${ }^{62}$ Škof ima v mislih eshatološko dopolnitev božje daritve, ki se za nas zgodi že v evharistiji. Razlikuje objektivni vidik, ki je 
Kristusov, in subjektivni vidik, ki je cerkveni. Poudariti velja, da ju razlikuje, ne pa loči.

Avguštin ni dvomil v to, da je evharistični kruh resnično Kristusovo telo, saj evharistijo razume kot oratio, prex, ki jo občestvo vernikov kot daritev dvigne k Bogu: sacrificium offerre. ${ }^{63}$ Hkrati jo razume kot prejeti dar občestva. ${ }^{64}$ Pri tem se zelo jasno prepletata kristološka in ekleziološka razsežnost zakramenta, saj je evharistija edina primerna, nedeljiva daritev Bogu, je daritev Kristusa in Cerkve. ${ }^{65}$ To pomeni, da je nemogoče, da bi jo obhajale ločene oz. shizmatične skupine.

Kakor do kruha in vina pride po naporni predelavi pšenice in grozdja, tako po poti katehumenata ljudje postanejo »Kristusovo telo«, sicer na drugačen način kot kruh in vino, ki sta posvečena, vendar na prav tako realen. Ko torej vernik prejme evharistični kruh, prejme telo Gospoda, ki je v svoji ljubezni sebi hotel pridružiti vse ljudi. Vernik tako prejme skupaj z Gospodom tudi samega sebe (Accipite, quod estis) in brate, ki z njim delijo isto vero. Prejmite to, kar ste! Prejmite kruh edinosti! To je prava evharistija, resnični zakrament edinosti Cerkve, saj jo uresničuje in izraža: ko jemo isti kruh, prebivamo vsi verniki, ki smo eno v Kristusu, edinem kruhu, v edinosti z Gospodom in med seboj. Ta Avguštinov pristop k evharistiji razširja razsežnost udeležbe pri gostiji in jo osvobaja od skušnjave individualizma. Po evharistiji Jezus pride v vernikovo srce, vendar ne sam, ampak skupaj z vsemi brati, ki jih on ljubi; pride s svojim hrepenenjem po odrešenju sveta, ki mora postati vernikovo hrepenenje in hrepenenje vse Cerkve. ${ }^{66}$

\section{Binom virtus - fructus sacramenti}

Qui accipit mysterium unitatis, et non tenet vinculum pacis, non mysterium accipit pro se, sed testimonium contra se. Conversi ad Dominum Deum Patrem omnipotentem, puro corde ei, quantum potest parvitas nostra, maximas atque veras gratias agamus; precantes toto animo singularem mansuetudinem eius, ut preces nostras in beneplacito suo exaudire dignetur; inimicum quoque a nostris actibus et cogitationibus sua virtute expellat, nobis multiplicet fidem, mentem gubernet, spiritales cogitationes concedat, et ad beatitudinem suam perducat: per Iesum Christum Filium eius. Amen.

63 Boyer (»L'eucharistie selon saint Augustin«, 126) pravi, da je Avguštin tako tesno izrazil povezavo med Kalvarijo in oltarjem, da je mnenja, da so nam Judje, ki so križali Jezusa, nevede pripravili evharistijo: "sed quando occiderunt, tunc nobis cenam nescientes praeparaverunt « (Sermo 112.1).

64 Marafioti, »Eucaristia e Chiesa«, 105.

$65 \mathrm{~V}$ delu $O$ Božjem mestu 10.20 in v Izpovedih 10.43.69 Avguštin govori o evharistiji kot o edini in popolni novozavezni daritvi, pri kateri je Kristus srednik, duhovnik in žrtev. Ta edina daritev nadomešča vse starozavezne daritve in postane edina daritev Cerkve, ki se pridružuje Kristusovi daritvi.

66 Caruso, »L'Eucaristia nella riflessione di Agostino«, 20. 
Kdor sprejme skrivnost edinosti, vendar ne ohranja vezi miru, ne sprejme skrivnosti za svoje rešenje, temveč pričuje proti sebi. Obrnimo se h Gospodu, Bogu Očetu vsemogočnemu in k njemu s čistim srcem, kolikor nam omogoča naša krhkost, dvignimo najglobljo in iskreno zahvalo; molimo Z vso dušo njegovo edinstveno dobroto, da bi po svoji milosrčnosti uslišal naše prošnje; naj izžene tudi iz naših dejanj in misli po svoji moči sovražnika, naj nam pomnoži vero, vodi pamet, podeli duhovno hrepenenje in nas pripelje v svoj raj: po Jezusu Kristusu svojem Sinu. Amen.

Ob sklepu govora Avguštin razlikuje med zakramentom in učinkovitostjo zakramenta: »Aliud est sacramentum, aliud virtus sacramenti.« (In Joa. evangelium 26.11) ${ }^{67}$ Zakrament lahko prejmejo vsi, toda odrešenjska moč zakramenta deluje le $\mathrm{v}$ tistem, ki ga prejme na pravi način, to pomeni v stanju milosti. ${ }^{68}$ Materialni elementi kruha in vina so res sacra, signum, visibile sacramentum, znamenje Kristusovega telesa in krvi, ki sta resnično navzoča v njem. Kristusovo telo in kri sta dar, ki ga lahko zaznamo v duhu, v veri. Tisti, ki se nevredno udeleži evharistije, sicer prejme Kristusovo telo in kri, ni pa deležen učinkovitosti zakramenta evharistije, to je občestva s Kristusom, odrešenja, ki ga Bog namenja v vseh časih vsem ljudem. V njem ne živi Kristus. ${ }^{69}$

Pri evharistiji se lahko zgodi, da človek sicer uživa kruh, Kristusovo telo, dejansko pa se ne združi z njim. O tem govori apostol Pavel, ko pravi, da kdor nevredno prejme evharistijo, jé svojo obsodbo (1 Kor 11.29). Udeležba pri evharistiji in stik s Cerkvijo lahko spremenita življenje vernika, lahko ga odrešita. Za to pa je potreben trden namen spremeniti življenje in ga usmeriti $\mathrm{k}$ Bogu, spreobrniti se. To so pogoji učinkovitosti zakramenta po Avguštinu. Evharistija je duhovna hrana, ki jo kristjan uživa na duhoven način, da bi v sebi imel duhovno življenje. Škof neofitom najprej priporoča, da naj bo duša oprana vsakršnega greha, saj se je skrivnosti mogoče približati samo s čistim srcem. Res sacramenti je ostati v Kristusu. ${ }^{70}$ Ko komentira Jn 6, poudarja, da se resnično hranijo tisti, ki v njem ostanejo in svoje življenje oblikujejo po njem. Torej se v resnici udeleži svete evharistije tisti, ki dejansko in »življenjsko« uživa Kristusovo telo. Vernik, ki tako uživa evharistijo, se pridruži Kristusu. Po evharistiji vernik živi Kristusovo življenje, saj je z njim eno telo. ${ }^{71}$

67 Za poglobitev razmerja med »res sacramenti« in »virtus sacramenti«: De Lubac, Corpus Mysticum, 217-21.

68 Marafioti, "Eucaristia e Chiesa«, 110.

69 Virtus sacramenti je milost Svetega Duha, ki izvira iz mesa in krvi na Kalvariji darovanega Kristusa in ki jo verniki osebno prejmejo pri evharistiji (Sage, "L'Eucaristie dans la pensée de saint Augustin«, 232).

70 Marafioti, »Eucaristia e Chiesa«, 113-14.

71 Gre za to, da ne bi uživali le zakramentalno Kristusovo telo in kri, ampak za to, da bi prišli do udeležbe pri njegovem Duhu in da bi ostali v njegovem telesu (Govori o Janezovem evangeliju 27.11). Po soudeležbi pri evharistiji verniki postanejo eno med seboj; evharistija uresničuje edinost Cerkve: "Vi torej prejemate to, kar ste začeli biti, če ga le vredno prejemate" (Govor 228/B). 


\section{Skrivnost edinosti}

Evharistija je mysterium unitatis. Avguštin zelo poudarja ta eklezialni vidik zakramenta. ${ }^{72}$ Razmišljanje o razmerju med evharistijo in edinostjo Cerkve izvira pri njem iz razkolnega konteksta (polemika $z$ donatisti), in sicer v prizadevanju za obnovo edinosti Cerkve v Afriki. Vsi udje Cerkve so združeni kot en sam oltar, kot eno samo Kristusovo telo. Preko svojega služenja je vedno bolj razumel, da Kristus ne more biti ločen od svojega telesa, Cerkve (Christus totus). ${ }^{73}$ Evharistični nauk je vedno povezan s kristološkim in ekleziološkim naukom. Enost Kristusa, Glave in Cerkve, ki je njegovo Telo, je popolnoma simbolizirana $\mathrm{v}$ zakramentalnih znamenjih evharistične gostije. To se v življenju udejanja kot obramba in iskanje edinosti, ki je bistvena značilnost Cerkve. Edinost Cerkve pa je vidno znamenje ljubezni, ki združi brate. "Ničesar drugega se ne sme kristjan bati kot ločitve od Kristusovega telesa." (Govori o Janezovem evangeliju 27.6)

Evharistija in občestvo Cerkve sta bistveno povezana. V Cerkev so združeni mnogi bratje in sestre, kakor je kruh zgneten iz mnogih zrn in vino izdelano iz mnogih grozdnih jagod. Ko kristjani zaužijejo evharistični kruh, postanejo eno telo. Občestvo, zbrano pri evharistiji, izraža občestvo vseh članov Cerkve in občestvo celotne Cerkve. Krščansko pojmovanje občestva ni več vezano na narodnost (Judje), ne na poklic (collegia pri Rimljanih), temveč na udeležbo pri Kristusovem telesu in krvi.

Značilnost tega kruha je edinost v smislu, da so tisti, ki postanejo udje Kristusovega telesa, tudi to, kar prejmejo. Takrat ta kruh postane vsakdanji kruh, pravi Avguštin, čeprav je tudi božja beseda kruh za dušo. V tem življenju nas hranita evharistični kruh in božja beseda, v novem življenju pa bomo božjo besedo gledali. ${ }^{74}$ Preden zrna postanejo kruh, morajo preko postopka priprave, prav kakor se dogaja s katehumenom, in sicer preko krstne vode, ognja maziljenja z oljem, ki je znamenje Svetega Duha. Evharistija je znamenje edinosti $v$ enem telesu, znamenje vere, upanja in ljubezni, medtem ko je krst pokop s Kristusom. $Z$ »Amen« podpišemo, da je to, kar vidimo, znamenje edinosti, in tudi, da je to, kar smo.

Po Avguštinu Bog od človeka ne zahteva zgolj zunanje daritve, temveč pričakuje to, znamenje česar je zunanja daritev. Vse, kar človek ima, je božje. To pomeni, da hiponski škof človeka vabi, naj samega sebe posveti Bogu, naj daruje svoje trpljenje v daritvi Cerkve, pa bo v evharistiji vredno prejel Kristusovo daritev. Prejeti daritev je - kot v Stari zavezi - dopolnitev udeležbe pri daritvi, to je jesti kruh, ki je v Novi zavezi daritev kristjanov (»manducare

\footnotetext{
72 Hamman, »Eucaristia«, 1265.

73 Prehod od zakramentalnega Kristusa k eklezialnemu (Cerkev) je izražen tudi v Homiliji 26 o Jn 6.45-59, ki razlaga najpomembnejši del Jezusovega evharističnega govora (Marafioti, »Eucaristia e Chiesa«, 110-111).

74 Di Nola, La dottrina eucaristica, 32-35.
} 
panem, quod est in novo testamento sacrificium christianorum«, O božjem mestu 18.5). Ko vernik izgovori »Amen«, potrjuje Kristusovo daritev, pa tudi svojo ter doseže posvetitev. ${ }^{75}$

Kdor učinkovito prejme Kristusovo telo, se v moči zakramenta spremeni v telo celega Kristusa (Christus totus), ki je Cerkev. V njej vsak živi iz življenja Svetega Duha. Zato Avguštin vzklika: »O sacramentum pietatis, signum unitatis, vinculum caritatis! «Pietas je krepost, ki ureja družinske odnose med starši in otroki, odnose otrok do staršev in odnose med brati. Evharistija je zakrament, sredstvo in orodje te kreposti, te Kristusove ljubezni do Očeta in do človeštva. Je znamenje edinosti med krščenimi, ki so združeni s Kristusom in med seboj, in je vez ljubezni, kajti Kristusova ljubezen v Duhu združuje vse z njim in med seboj. ${ }^{76}$ Prvi učinek (res sacramenti), ki izhaja iz evharistije, je Cerkev, drugi je večno življenje tistih, ki v Cerkvi živijo in se hranijo z evharističnim kruhom. Kdor se učinkovito (ne samo zakramentalno, ali zunanje - temporaliter, ampak usque ad participationem spiritus) hrani z evharističnim kruhom, ostane $\mathrm{v}$ Kristusu in prejme milost vztrajanja tudi $\mathrm{v}$ preganjanju (Govor 27 o Jn 6).

Avguštin uči, da, tako kot donatisti neučinkovito prejemajo zakrament krsta zato, ker krst ne posvečuje nepravilno razpoloženih krščenih, čeprav je zakrament shizmatikov sam po sebi veljaven, v zakramentu evharistije sicer prejmejo Kristusovo telo, učinki svetosti pa so zaradi istega razloga nedejavni. ${ }^{77}$ Kot smo že omenili, Avguštin razlikuje med communio sacramentorum in communio sanctorum. Communio sacramentorum, zakramentalno občestvo, je zunanje občestvo katoliške Cerkve, to je Cerkve vseh narodov (ecclesia catholica, ecclesia omnium gentium). To občestvo gradi izpoved iste vere, udeležba pri istih zakramentih, priznavanje istega nauka. Na zunaj gre za eno telo - corpus permixtum (De doct. christ. 3.32.45), ki ga je mogoče primerjati s poljem, na katerem sta navzoči tako ljuljka kot pšenica, ali z mrežo, v kateri so hkrati dobre in slabe ribe. Ne gre torej za dve telesi (corpus bipartitum), o katerih je govoril donatist Tihonij. Communio sanctorum pa je resnično Kristusovo telo, resnična Cerkev, kjer prebiva ljubezen, caritas, gratia, Sanctus Spiritus. Donatisti so Cerkev zelo strogo pojmovali kot občestvo svetih. Avguštin pa razlaga, da nekateri, ki so sicer v zakramentalnem občestvu, zaradi greha ne živijo v Cerkvi (»qui per communionem sacramentorum intus videntur et per iniquitatem morum foris intelliguntur«, Contra litteras Petiliani 2.80.178). Torej gre za zunanjo in notranjo raven. Ta slednja je pristna, resnična, čeprav gre za eno samo resničnost Cerkve, v kateri se vidni elementi nanašajo na poslednji temelj Cerkve, to je na Svetega Duha. Communio sacramentorum vključuje communio sanctorum, to pa še ni zagotovilo, da so vsi vključeni v communio sanctorum. Zato je pomembno biti in ostati živ ud

\footnotetext{
75 Van der Lof, »Eucaristie et présence réelle«, 301-302.

76 Marafioti, »Eucaristia e Chiesa«, 112-15.

77 Boyer, »'eucharistie selon saint Augustin«, 128.
} 
Kristusovega telesa, ostati v edinosti Cerkve, ne glede na to, da je v njej navzoča tudi ljuljka. ${ }^{78}$ Resničnost communio sanctorum, pridruženosti Kristusu, se izkaže v zmožnosti radikalne ljubezni, tj. ljubezni, kot jo je izkazal Kristus. Avguštin pravi, da to ljubezen spoznamo po mučencih, ki so se darovali za Kristusa. ${ }^{79}$ Evharistija je tesno povezana s Kristusovo daritvijo življenja za svet in s Cerkvijo kot občestvom Kristusovih učencev. Učlovečenje Božjega Sina je dogodek, ki globoko spreminja smisel zgodovine sveta in ga pripelje nazaj k prvotnemu stanju edinosti in harmonije s Stvarnikom, ki jo je greh porušil. Imeti isto mišljenje, kakor je v Jezusu Kristusu, pomeni ljubiti se med seboj, biti radodarni do ubogih, razširjati v svetu dišeč vonj evharistije, ki vse zbere v eno. ${ }^{80}$

\section{EVHARISTIJA "SACRAMENTUM REDEMPTIONIS“ V GOVORU 227}

Na prvi pogled se zdi, da je Govor $227^{81}$ zelo podoben Govoru 272. Razlika je le v tem, da razlagalci menijo, da je Avguštin prvega imel med velikonočnim bogoslužjem, drugega pa, kakor smo videli, morda med binkoštnim. Pozorno branje besedila pa pokaže na precej drugačno perspektivo, kot jo najdemo v Govoru 272, kar nam torej omogoča opozoriti še na druge odtenke Avguštinovega evharističnega nauka, ki jih želimo v nadaljevanju prikazati. Zato bomo spet postopoma, tudi tokrat v sklopih, podali prevod in analizirali vsebino. Razdelili jo bomo v štiri dele, ki pa se zdaj zvrstijo v drugačnem vrstnem redu kot v Govoru 272, in sicer: binom signum - res; binom Kristusovo telo - mistično telo Cerkve; binom fides - ratio; binom virtus - fructus

78 Marafioti, »Eucaristia e Chiesa«, 114-15.

79 Evharistija je dar Kristusove ljubezni, ki nas usposablja za darovanje življenja. Tako Avguštin predstavlja ta vidik, ko razlaga Janezov evangelij: » «Nihče nima večje ljubezni, kakor je ta, da kdo da življenje za svoje prijatelje« (Jn 15.13). "Kakor je Kristus dal življenje za nas, tako moramo tudi mi dati življenje za brate« (1 Jn 3.16). To beremo v Salomonovih pregovorih: »Kadar sedeš k obedu z veljakom, dobro premisli, koga imaš pred seboj. Pomisli, da boš tudi ti pripravil nekaj podobnega «(Prg 23.1-2). Katera je ta miza veljaka? To je miza, kjer prejemamo telo in kri njega, ki se daruje za nas. Torej pripraviti nekaj podobnega pomeni biti pripravljeni dati življenje za brate. Peter pravi: »Saj je tudi Kristus trpel za vas in vam zapustil zgled, da bi hodili po njegovih stopinjah« (1 Pt 2.21). To so uresničili mučenci. Tudi mi smo poklicani vračati isti dar. Ne mislimo pa, da smo njemu enaki, saj ima on oblast dati življenje, da ga spet prejme ( Jn 10.18); on je v sebi uničil smrt; njegovo telo ni poznalo trohnobe; on ni potreboval nas, da bi nas rešil, medtem, ko mi nič ne moremo brez njega. On je svojo kri prelil za odpuščanje grehov in nam s tem ni dal zgled, da bi ga posnemali, namreč dar, da bi se mu zahvalili« (Govori o Janezovem evangeliju 84 ).

80 Adam se je po grehu ločil od Boga, toda Bog zaradi tega ni opustil zamisli enosti in miru za vse človeštvo. V Kristusu se je za vse človeštvo dopolnil načrt enosti, ki je sad občestva Svete Trojice, sad ljubezni med različnimi osebami, ne izločitve različnosti (Ratzinger, La comunione nella Chiesa, 16-17).

81 Govor 227 je običajno vezan na Govor 226, saj naj bi Avguštin imel oba govora isti dan (Poque, Introduction, 129). Odsotnost polemike proti donatistom kaže na čas po letu 411 (Poque, Introduction, 29). Govor 227 naj bi bil izrečen za veliko noč leta 412 ali 413 (Poque, Introduction, 130). 
sacramenti. Po našem mnenju je v govoru izpostavljen soteriološki vidik zakramenta evharistije.

\title{
Binom signum - res
}

Hiponski škof že na začetku govora nakaže bistvo evharistične kateheze. Pravi namreč:

\begin{abstract}
Memor sum promissionis meae. Promiseram enim vobis, qui baptizati estis, sermonem quo exponerem mensae Dominicae Sacramentum, quod modo etiam videtis et cuius nocte praeterita participes facti estis. Debetis scire quid accepistis, quid accepturi estis, quid quotidie accipere debeatis. Panis ille quem videtis in altari sanctificatus per verbum Dei, corpus est Christi. Calix ille, immo quod habet calix, sanctificatum per verbum Dei, sanguis est Christi. Per ista voluit Dominus Christus commendare corpus et sanguinem suum, quem pro nobis fudit in remissionem peccatorum. Si bene accepistis, vos estis quod accepistis.
\end{abstract}

Spominjam se svoje obljube. Vam, ki ste bili krščeni, sem obljubil govor, v katerem bi predstavil zakrament Gospodove mize, ki ga tudi vidite in ste se ga sinoči udeležili. Vedeti morate, kaj prejemate, kaj boste prejeli, kaj boste morali vsak dan prejeti. Kruh, ki ga vidite na oltarju, posvečen $\mathrm{z}$ božjo besedo, je Kristusovo telo. Kelih, oziroma to, kar kelih napolnjuje, posvečeno $\mathrm{z}$ božjo besedo, je Kristusova kri. Po kruhu in vinu nam je Kristus Gospod hotel zaupati svoje telo in kri, ki jo je prelil za nas v odpuščanje grehov. Če ste to lepo prejeli, ste to, kar ste prejeli.

Najprej je viden zakramentalni realizem, materialni in besedni del zakramenta, na katerega Avguštin opozarja novokrščene. Toda našo pozornost takoj pritegne soteriološka misel, ki sledi, in sicer, da je bila Kristusova kri prelita za nas v odpuščanje grehov. Škof izraža udeležbo pri evharistiji z besedami: uživati njegovo meso, postati ud njegovega telesa, piti njegovo kri (manducatores et potatores carnis et sanguinis sui; Govori o Janezovem evangeliju 31.11; 26.13-18; 2.11).

Prelita kri pomeni smrt. Kristus ji je dal smisel, ko je tudi sam prelil svojo kri za odrešenje sveta. Ko Avguštin govori o Kristusovi smrti, pravi, da ima smisel zato, ker jo je on ponižno sprejel (Govori o Janezovem evangeliju 119.4). Gre za smrt, ki daje življenje drugim, saj gre za smrt kralja narodov. Ta smrt je zmaga in ne poraz, kakor običajno opredelimo smrt ljudi. Kristusova smrt izraža njegovo največjo svobodo in upanje za vse človeštvo. Kristus smrti, ki ga je doletela, ni sprejel pasivno, ampak je pričakoval njeno uro, podobno kot je pričakoval uro učlovečenja. Zaradi te svobode ima njegova smrt vrednost darovanja življenja. Njegova smrt ni zaključek neke življenjske zgodbe, temveč del njegovega poslanstva, ki mu ga je izročil Oče. Tako so tisti, ki so pre- 
jeli in pili njegovo kri kot dar, prejeli osvoboditev in odpuščanje za to, ker so ga usmrtili, kakor pravi v Govoru o Janezovem evangeliju 38.7. ${ }^{82}$

Odrešenje imamo po Kristusovi krvi, v njem odpuščanje grehov (Kol 1.12; Ef 1.3-7). Ta Pavlova misel ${ }^{83}$ je temelj Avguštinovega nauka o odrešenju (Pretium quippe redemptionis nostrae sanguis est Christi, Ep.149.2.20), pri katerem se bomo kasneje nekoliko zadržali.

\section{Kristusovo telo - mistično telo Cerkve}

Govor v nadaljevanju razvija temo enosti in različnosti. Kot običajno, hiponski škof uporabi že znano Pavlovo prispodobo kruha oz. telesa, ki simbolizirata skrivnost Cerkve. ${ }^{84}$ Sledi paralelizem med pripravo kruha in potjo katehumenov, da bi postali to, kar bodo prejeli, resnično Kristusovo mistično telo.

Apostolus enim dicit: Unus panis, unum corpus, multi sumus. Sic exposuit sacramentum mensae Dominicae: Unus panis, unum corpus, multi sumus. Commendatur vobis in isto pane quomodo unitatem amare debeatis. Numquid enim panis ille de uno grano factus est? Nonne multa erant tritici grana? Sed antequam ad panem venirent, separata erant; per aquam coniuncta sunt post quamdam contritionem. Nisi enim molatur triticum et per aquam conspergatur, ad istam formam minime venit, quae panis vocatur. Sic et vos ante ieiunii humiliatione et exorcismi sacramento quasi molebamini. Accessit baptismum et aqua quasi conspersi estis, ut ad formam panis veniretis. Sed nondum est panis sine igne. Quid ergo significat ignis, hoc est chrisma olei? Etenim ignis nutritor Spiritus Sancti est sacramentum. In Actibus Apostolorum advertite quando legitur; modo enim incipit liber ipse legi: hodie coepit liber qui vocatur Actuum Apostolorum. Qui vult proficere, habet unde. Quando convenitis ad ecclesiam, tollite fabulas vanas; intenti estote ad Scripturas. Codices vestri nos sumus. Attendite ergo et videte, qua venturus est Pentecoste Spiritus Sanctus. Et sic veniet: in linguis igneis se ostendit. Inspirat enim caritatem qua ardeamus in Deum et mundum contemnamus et foenum nostrum exuratur et cor quasi aurum purgetur. Accedit ergo Spiritus Sanctus, post aquam ignis et efficimini panis quod est corpus Christi. Et ideo unitas quodam modo significatur.

82 Grossi, »Note al binomio "Sangue sparso e remissione dei peccati” sino a s. Agostino«, 1222.

83 Glede Avguštinove eksegeze Pavlovih pisem glej: Mara, Agostino interprete di Paolo.

84 Avguštin je izrazito poudaril vidik edinosti preko prispodobe mnogih zrn, ki postanejo en sam kruh. Gre za temo, ki spremlja patristično razmišljanje o evharistiji že od Didahe oz. Nauka dvanajstih apostolov (Pellegrino, Introduzione generale, L): "Kakor je bil ta kruh, ki ga lomimo, raztresen po gorah in je zgneten postal eno, tako naj se zbere tvoja Cerkev od koncev zemlje v tvoje kraljestvo« (9.4). "Zanimivo je, da je molitev za edinost Cerkve navzoča že ob samem začetku, ko še ni bilo na vidiku delitev kasnejših stoletij« (Špelič, »Evharistija pri cerkvenih očetih«, 64). Za poglobitev tematike evharistije kot zakramenta edinosti glej: Cattaneo, "Dalla parola all'eucaristia«, 345-373. 
Apostol pravi namreč: „En sam kruh, eno telo, čeprav nas je veliko.« Tako je predstavil zakrament Gospodove mize: „En sam kruh, eno telo, čeprav nas je veliko."V tem kruhu vam je zaupano, kako morate ljubiti enost. Je mar namreč kruh narejen iz enega zrna? Mar ni bilo veliko pšeničnih zrn? Vendar preden so postala kruh, so bila ločena; po vodi so se združila, potem ko so bila nekako zmleta. Če namreč pšenica ne bi bila zmleta in zgnetena z vodo, sploh ne bi prišla do tiste oblike, ki jo imenujemo kruh. Tako ste bili tudi vi po ponižanju posta in po zakramentu eksorcizma kakor zmleti. Potem ste bili krščeni in kakor zmočeni z vodo, da bi dospeli do oblike kruha. Vendar kruha še ni brez ognja. Kaj torej pomeni ogenj, je to maziljenje z oljem? Olje, ki je gorivo za ogenj, je zakrament Svetega Duha. Bodite pozorni, ko berete Apostolska dela; zdaj namreč začenjamo brati ta knjiga: danes se začne knjiga, ki se imenuje Actuum Apostolorum. Kdor želi napredovati, lahko zajame tukaj. Ko se zberete v cerkvi, pustite prazne besede; bodite pozorni na Sveto pismo. Mi smo vaše knjige. Bodite pozorni torej in glejte, kako je Sveti Duh prišel na binkošti. Tako bo prišel, da se razodene v ognjenih jezikih. Navdihuje namreč ljubezen, s katero gorimo za Boga in tožimo svet, vžge naše pleve in prečiščuje srce kot zlato. Sveti Duh, ogenj, pride torej po vodi, in vi postanete kruh, ki je Kristusovo telo. In glej, na ta način je upodobljena enost.

\section{Binom fides - ratio}

Za to, da bi človek spoznal Kristusa, mora pripadati Cerkvi in živeti v edinosti s Kristusovim telesom. Tudi za to da bi vredno prejel evharistijo, mora pripadati Kristusovemu mističnemu telesu kot živi ud. Vernik mora biti, preden se približa k oltarju, očiščen, zato se priprava na prejem zakramenta nadaljuje tudi v teku obhajanja svete daritve. Povabilu: »Kvišku srca!« sledi še Gospodova molitev, s katero verniki prosijo za odpuščanje grehov, da ne bi prejeli obhajila v svojo obsodbo. ${ }^{85} \mathrm{Ta}$ del govora je namenjen razlagi darovanjskega dela sv. maše.

Tenetis sacramenta ordine suo. Primo, post orationem, admonemini sursum habere cor; hoc decet membra Christi. Si enim membra Christi facti estis, caput vestrum ubi est? Membra habent caput. Si caput non praecessisset, membra non sequerentur. Quo ivit caput nostrum? Quid reddidistis in Symbolo? Tertia die resurrexit a mortuis, ascendit in caelum, sedet ad dexteram Patris. Ergo in caelo caput nostrum. Ideo cum dicitur: Sursum cor, respondetis: Habemus ad Dominum. Et ne hoc ipsum quod cor habetis sursum ad Dominum, tribuatis viribus vestris, meritis vestris, laboribus vestris, quia Dei donum est sursum habere cor, ideo sequitur episcopus, vel

85 Boyer, »L'eucharistie selon saint Augustin«, 127. 
presbiter qui offert et dicit - cum respondent populus: Habemus ad Dominum sursum cor -: Gratias agamus Domino Deo nostro, quia sursum cor habemus. Gratias agamus, quia nisi donaret in terra cor haberemus. Et vos attestamini dicentes: Dignum et iustum est, ut ei gratias agamus qui nos fecit sursum ad nostrum caput habere cor. Deinde post sanctificationem sacrificii Dei, quia nos ipsos voluit esse sacrificium suum, quod demonstratum est, ubi impositum est primum illud sacrificium Dei et nos - id est signum rei - quod sumus; ecce ubi est peracta sanctificatio dicimus Orationem Dominicam, quam accepistis et reddidistis. Post ipsam dicitur: Pax vobiscum et osculantur Christiani in osculo sancto. Pacis signum est: sicut ostendunt labia, fiat in conscientia, id est, quomodo labia tua ad labia fratris tui accedunt, sic cor tuum a corde eius non recedat.

Poznate red, po katerem se obhajajo zakramenti. Najprej ste po molitvi pozvani dvigniti srca kvišku; to se Kristusovim udom spodobi. Če ste namreč postali Kristusovi udje, kje je vaša glava? Udje imajo glavo. Če glava ne bi šla naprej, ji udje ne bi sledili. Kam je šla naša glava? Kaj ste izpovedali v veroizpovedi? »Tretji dan je od mrtvih vstal, šel v nebesa, sedi na desnici Očetovi.« Torej naša glava je v nebesih. Zato, ko se reče: »Kvišku srca«, odgovorite, »Imamo jih pri Gospodu«. In da ne bi to, da imate srce pri Gospodu, pripisali svojim močem, svojim zaslugam, svojim delom, kajti dvigniti srce kvišku je božji dar, zato škof ali duhovnik, ki daruje, nadaljuje in pravi - potem ko je ljudstvo odgovorilo: »Imamo jih pri Gospodu«, - "Zahvalimo se Gospodu, našemu Bogu«, kajti so naša srca dvignjena kvišku. »Zahvalimo se Gospodu«, kajti če nam tega ne bi dal on, bi imeli srce na zemlji. In vi to potrjujete, ko pravite: "Spodobi se in pravično je«, da se zahvalimo njemu, ki nam je dal, da so naša srca dvignjena kvišku, k naši glavi. Potem, po posvetitvi božje daritve, kajti hotel je, da bi mi bili njegova daritev, kar je dokazano s tem, da je postavljena božja daritev in smo postavljeni mi - to je znamenje te resničnosti (signum rei) $)^{86}$ - to, kar smo; glej, po posvetitvi molimo Gospodovo molitev, ki ste jo prejeli in jo izrekli. Po njej se reče: »Mir z vami«, in si kristjani izmenjajo svet poljub. To je znamenje miru: to, kar izražajo ustnice, naj bo v srcu, se pravi, kakor se tvoje ustnice približajo ustnicam tvojega brata, tako naj se tvoje srce ne oddaljuje od njegovega srca.

Iz odlomka je zelo razviden mistagoški namen Avguštinovega govora. Škof stopi v dialog z novokrščenimi, upoštevajoč njihovo znanje, ki se opira predvsem na veroizpoved. Nadaljnje razlage krščanskega nauka se morajo torej razumsko uskladiti s členi veroizpovedi. Tudi tokrat je v tej dinamiki med vero in razumom mogoče razbrati določeno perspektivo v Avguštinovi predstavitvi zakramenta in njegovega bogoslužnega poteka. Kristjani ne morejo pripisovati svojim močem ali zaslugam svojih del dejstva, da imajo srce pri Gospodu. To je božji dar, kar je tudi dokazano s tem, da je to tudi edina stvar, za katero je smiselno zahvaliti se Bogu.

86 Zanimiv paralelizem s tem besedilom najdemo v delu O božjem mestu 10.6. 


\section{Binom virtus - fructus sacramenti}

Končno se Avguštin vrača k priljubljenemu poudarjanju pogojev za vredno in učinkovito prejemanje zakramenta. Nato govor sklene s pogledom na nebeško razsežnost.

Magna ergo sacramenta et valde magna. Vultis nosse quomodo commendentur? Ait Apostolus: Qui manducat corpus Christi aut bibit calicem Domini indigne, reus est corporis et sanguinis Domini. Quid est indigne accipere? Contemptibiliter accipere, irridenter accipere. Non tibi videatur vile, quia vides. Quod vides transit, sed quod significatur invisibile non transit, sed permanet. Ecce accipitur, comeditur, consumitur. Numquid corpus Christi consumitur? numquid Ecclesia Christi consumitur? numquid membra Christi consumuntur? Absit. Hic mundantur, ibi coronantur. Manebit ergo quod significatur, quamquam transire videatur illud quod significat. Sic ergo accipite ut vos cogitetis, unitatem in corde habeatis, sursum cor semper figatis. Spes vestra non sit in terra, sed in caelo; fides vestra firma sit in Deum, acceptabilis sit Deo. Quia quod modo hic non videtis et creditis, visuri estis illic, ubi sine fine gaudebitis.

Torej veliki zakramenti, zares veliki. Ali bi radi vedeli, kako so nam bili zaupani? Apostol pravi: »Kdor jé Kristusovo telo ali pije iz Gospodovega keliha nevredno, se bo pregrešil nad Gospodovim telesom in krvjo.« Kaj pomeni nevredno prejeti? Prejeti nagajivo, prejeti nespoštljivo. Naj se ti ne zdi majhne vrednosti zato, ker vidiš. To, kar vidiš, mine, toda to, kar je nevidno in izraženo v znamenju, ne mine, temveč ostane. To prejmemo, uživamo, uporabljamo. Mar je Kristusovo telo izrabljeno? Mar je Kristusova Cerkev izrabljena? Mar so Kristusovi udje izrabljeni? Nikakor. Tukaj so očiščeni, tam bodo ovenčani. Ostane torej to, kar je izraženo v znamenju, čeprav se zdi, da mine to, kar ima pomen. Prejmite torej tako, da mislite, da imate v srcu edinost, da imate srce vedno kvišku. Naj ne bo vaše upanje na zemlji, temveč v nebesih; naj bo vaša vera stanovitna v Bogu, naj bo sprejemljiva Bogu. To, česar na neki način tukaj ne vidite, ampak v kar verujete, boste videli tam, kjer ga boste uživali brez konca.

Med vrsticami jasno prepoznamo namig na delitev res - signum: prva ostane, drugi pa mine. Avguštin jo aplicira na edinost, ki jo bo v polnosti uživalo občestvo tistih, ki uživajo Kristusovo telo in kri, ki sta resnična hrana in resnična pijača. Na zemlji pa je edinost le na ravni znamenja. Avguštin preide od zemeljske k eshatološki razsežnosti, saj je vernik po evharistiji deležen Kristusovega življenja, ki je večno življenje svetih. ${ }^{87} \mathrm{~V}$ Cerkvi, ki je sedaj romarica na zemlji, sobivajo vsi, ki se udeležujejo evharistije, bodisi duhovno bodisi le obredno, materialno. Ob koncu časov pa bodo eni prejeli večno po-

87 De Lubac (Corpus Mysticum, 227-28) poudarja v Avguštinovem evharističnem nauku ta prehod od zakramentalnega k eklezialnemu telesu. Glej tudi: Marafioti, »Eucaristia e Chiesa«, 113-16. 
gubo, drugi pa občestvo z Bogom, in sicer tisti, ki se z vsem, kar so, udeležujejo zakramenta, ga prejemajo v stanju božje milosti in edinosti Kristusovega telesa, ki je Cerkev; postanejo torej eno s Kristusom, sedaj na zemeljskem romanju, potem pa v večnosti pri Očetu.

\section{Zakrament odrešenja}

Poleg eklezialnega vidika, ki je v tem govoru prav tako izpostavljen kot v prejšnjem, Avguštin poudarja soteriološko razsežnost zakramenta evharistije, ki jo zasledimo na začetku Govora 227, in sicer ko pravi, da je Kristusova kri prelita za nas v odpuščanje grehov. ${ }^{88}$ Evharistija je sacramentum redemptionis, ki vključuje Kristusovo delo odrešenja od smrti do vstajenja. V njej je odrešilno navzoč Jezus Kristus v resničnem telesu in krvi.

Po evharistiji je Kristus navzoč kot žrtev za odrešenje sveta. Zakrament ponavzočuje njegovo smrt v mašni daritvi: Kristus se je sicer daroval enkrat za vselej, v liturgični skrivnosti pa se ne preneha darovati vsak dan, kot smo videli v že omenjenem Pismu 98.9. V evharistični daritvi se dan za dnem uresničuje popolna daritev, pri kateri je Kristus žrtev in duhovnik; to je daritev, ki je dopolnila vse starozavezne daritve. ${ }^{89}$ On je Srednik, ki v božji naravi skupaj z Očetom sprejme daritev, v človeški naravi pa je sam žrtev, daritev. On je hotel, da se ta daritev Cerkve, ki je njegovo telo, obhaja vsak dan in tako Cerkev po njem daruje samo sebe. Stare daritve so bile različna znamenja te največje in prave daritve (O božjem mestu 10.20). Kristus edini lahko daruje sveto in popolno daritev. On je duhovnik brez madeža, čista žrtev, popoln Srednik, ki z Očetom sprejema daritev in jo hkrati daruje za človeštvo, s katerim se je združil..$^{\circ}$ Avguštin vidi v Kristusovem duhov-

88 Tema prelite krvi (sanguis effusus) je bila zelo običajna že v zgodnjih apostolskih časih. Pri Avguštinu jo zasledimo med letoma 406 in 418 . V tem obdobju si je prizadeval za pojasnjevanje teoloških pojmov v boju z donatisti (zakramente ima Cerkev, ne pa delivec) in pelagijanci (Kristus je dal življenje za vse, ne le za nekatere odrasle, ki imajo razvito vest in so odgovorni za svoje ravnanje). V temi prelite krvi se zakramentalno vprašanje prepleta s soteriološkim vprašanjem Kristusove smrti (Grossi, „Note al binomio 'Sangue sparso e remissione dei peccati' sino a s. Agostino«, 1226-1231).

89 Daritev Judov, razlaga Avguštin, je bila po Aronovem duhovništvu daritev živali. To še ni bila daritev Gospodovega telesa in krvi, ki jo poznajo tisti, ki so brali evangelij, in ki je sedaj razširjena po vsem svetu. Druga daritev je bila po Melkizedekovem redu, o katerem Ps 110.4 pravi: »Ti si duhovnik na veke« in v podobi govori o našem Gospodu Jezusu Kristusu. Melkizedek je bil salemski kralj. Salem je mesto, ki so ga potem imenovali Jeruzalem. Preden so kraljevali Judje, je bil tam Melkizedek, duhovnik Boga najvišjega, ki je prišel naproti Abrahamu, ko je ta osvobodil Lota, svojega brata (1 Mz 14). Melkizedek je bil tako velik, da je Abrahama blagoslovil. Daroval je kruh in vino, blagoslovil Abrahama in ta mu je dal desetino. O Kristusu je torej rečeno, da je duhovnik na veke po Melkizedekovem redu. On se je ponižal do smrti na križu, da bi nam s križa pokazal na novo daritev: Gospodovo meso in kri (Razlaga Ps 33.1.5-6).

90 Avguštin razlaga, da pri vsaki daritvi pridejo do izraza štirje dejavniki: komu se daruje, kdo daruje, kaj se daruje in za koga se daruje. Ti dejavniki so v Kristusu, edinem Sredniku, združeni v eni sami daritvi, v kateri je on eno z Očetom, ki se mu daruje, hkrati pa eno z brati, za katere se daruje, torej istočasno duhovnik in žrtev (O Trojici 4.14.19). 
ništvu dopolnitev duhovništva po Melkizedekovem redu (Ps 110 in Heb 5). To je večno duhovništvo, ki ni vezano na zgodovinske institucije izraelskega ljudstva. Kristus je postal duhovnik in daritev, da bi človeku posredoval svoje življenje in mu omogočil slediti njegovemu zgledu. Na oltarju kristjani darujemo sami sebe: »To je daritev kristjanov: eno telo, čeprav nas je veliko. Cerkev s tem zakramentom, ki je vernikom znan, obhaja to skrivnost, kajti v njem se razodene, da je v tem, kar je darovano, darovana ona sama.« $(O$ božjem mestu 10.6) ${ }^{91}$

Evharistija je zakrament odrešenja, saj Avguštin pravi, da je v občestvu s Kristusovim telesom in krvjo odrešenje vernikov, njihova možnost za odnos z Bogom. Kako je to mogoče, če je človek človek, materialno bitje, Bog pa je duh? Avguštin vidi v evharistiji neke vrste podaljšanje kénosis, to je ponižanja, sklanjanja, ki se je začelo z učlovečenjem..$^{92}$ Večna Beseda, večni Logos, nevidni postane vidni, nedoumljivi postane hrana, láhka za uživanje in prebavo (»mleko« piše Avguštin in se nanaša na Heb 5,13-14 in 1 Pt 2,2). Torej vidi v evharistiji novo znamenje božje naklonjenosti, ki stoji za vso ojkonomijo odrešenja. Po svojem telesu in krvi nam je Kristus daroval odrešenje. $\mathrm{Na}$ kakšen način? S ponižnostjo. Če ne bi bil ponižen, ga ne bi mogli niti uživati niti piti. »Beseda je postala meso in je prebivala med nami« (Jn 1,14). Človek uživa kruh angelov (Ps 78,24-25), to Besedo, ki se je učlovečila, človek uživa. On je sam sebe izničil, podobo hlapca vzel nase, postal ponižen do smrti na križu (Flp 2,6-8). S samega križa nam je pokazal novo daritev: Gospodovo meso in kri (Razlaga Ps 33.1.6). Božja ponižnost je bila veliko odkritje Avguština. ${ }^{93}$ Bog, ki je onstran vsega, kar si lahko zamislimo, nam je prišel blizu preko svetopisemskih besed, v katerih moramo iskati, s čim nas hrani, tako kot moramo streti oreh, da bi odkrili, kaj je v njem. Zgodovina odrešenja se od božjega sestopa v Kristusu preko učlovečenja odvije preko skrajnega ponižanja na križu in vstajenja. Torej ima svoj vrhunec v velikonočni skrivnosti, ki jo obhajamo v evharistiji.

Zgodovinski trenutek prelitja krvi na križu je zakramentalno ponavzočen pri obhajanju evharistije. Tako se povezuje udeležba pri Kristusovi pashi, ko je Jezus dal svoje življenje, in odrešenje za tiste, ki verujejo in so pashe deležni. Avguštin je glede pashe podedoval dve izročili in ju združil, in sicer pasho kot prehod in pasho kot trpljenje: Gospodova pasha ${ }^{94}$ je njegovo trpljenje, darovanje, prelita kri, smrt. Pasha kristjanov je obhajanje evharistije,

91 »Hoc est sacrificium Christianorum: Multi unum corpus in Christo. Quod etiam sacramento altaris fidelibus noto frequentat Ecclesia, ubi ei demonstratur, quod in ea re, quam offert, ipsa offeratur" (De civ. Dei 10.6).

92 Evharistija, tako velik in božji zakrament, kakor pravi Avguštin, je tesno povezana z učlovečenjem, saj sam pravi: „Če Gospod angelov ne bi postal človek, ne bi imeli njegovega mesa; če ne bi imeli njegovega mesa, ne bi uživali kruha z oltarja« (Govor 130.2).

93 Marafioti, »Eucaristia e Chiesa«, 107.

94 Velja spomniti, da je v svetopisemski tipologiji evharistija uresničenje pashe, zaveze, daritve in gostije (Turnšek, »Zakramenti«, 261-64). 
pri kateri pijejo Kristusovo kri. ${ }^{95}$ Ko Avguštin razlaga te reči (Govori o Janezovem evangeliju 55.1), poudarja, da je Kristus pravo Jagnje, ki je darovano, ${ }^{96}$ mi pa smo po njegovi daritvi osvobojeni pogube in obhajamo zelo zdravilen prehod, ko preidemo iz teme v Kristusovo luč, iz sveta v njegovo kraljestvo. Piti njegovo prelito kri torej pomeni udeležiti se Kristusovega odrešenja in odpuščanja. Evharistija je udeležba pri skrivnosti Kristusovega življenja in luči, pri skrivnosti njegovega odrešenja in osvoboditve. Tisti, ki se udeležijo evharistije, so poklicani, da ne bi samo zakramentalno uživali telo in kri Jezusa Kristusa, temveč da bi ga uživali tako, da bi prišli do občestva z njegovim Duhom in bi ostali v njegovem telesu, ki je Cerkev (Govori o Janezovem evangeliju 27.11).

Iz Kristusove prebodene strani sta pritekli kri in voda za odpuščanje grehov. Voda pa je hkrati pijača in kopel. S krvjo in vodo je pripravil svojo nevesto - pravi Avguštin (Govori o Janezovem evangeliju 120.2). Cerkev se rodi iz prebodene strani novega Adama. Iz tega torej sledi, da je Cerkev občestvo ljudi, ki izhajajo iz njegove strani in so odrešeni po zakramentih Cerkve, v katerih je navzoč sam Kristus.

Tukaj najdemo jasna povezavo med prelivanjem krvi in odpuščanjem grehov. V Avguštinovem času so obstajali trije načini odpuščanja: 1. krst, ki ga je človek prejel enkrat za vselej (semel); 2. molitev očenaš, ki je vsakdanji krst; 3. javna pokora, ki jo je človek mogel vzeti nase samo enkrat v življenju. Avguštin povezuje odpuščanje grehov s Kristusovo krvjo, ki je temelj vsega, s Svetim Duhom, ki uresničuje odpuščanje, in s Cerkvijo, kjer je odpuščanje možno.

Samo po sebi se za tem razmišljanjem skriva pastoralno vprašanje, in sicer o tem, kako širok je spekter odpuščanja Cerkve za težke grehe. V Ciprijanovem času, na primer, za prešuštvo ni bilo odpuščanja. To pomeni, da ti grešniki niso smeli pristopiti k pokori in seveda tudi k obhajilu ne. Že prej se je tudi Tertulijan strogo izrazil v zvezi s tem. Avguštinu pa je bilo vse bolj jasno, da je usmiljenje najvišji cilj krščanskega življenja. Vir sprave je vedno Jezusova smrt na križu, kjer je bila prelita njegova kri v odpuščanje grehov.

95 Gre za gostijo, na katero smo povabljeni, pravi Avguštin, ko razlaga priliko o gostiji ( $L k$ 14.1524). V evangeliju smo povabljeni na gostijo, ki jo je priredil Srednik med Bogom in človekom, to je Jezus Kristus (1 Tim 2.5). Povabljeni, ki so jih poklicali preroki, so Kristusa ubili! S tem so nam, ne da bi vedeli, pripravili pravo gostijo. Potem ko je bil Kristus darovan, potem ko je vstal od mrtvih, so učenci spoznali Gospodovo gostijo, ki jo je Kristus postavil s svojimi rokami in besedami in na katero so bili povabljeni (Govor 112.1). Tudi v delu O Božjem mestu govori o evharistiji kot o gostiji in daritvi: božja beseda kliče na gostijo, na kateri je ona sama žrtev: biti deležni njegove mize pomeni imeti življenje. Tako pravi Pridigar: „Ni sreče za človeka pod soncem, razen da jé in pije in se veseli« (Prd 8.15). Tu govori o udeležbi pri mizi, ki jo je daroval duhovnik, Srednik nove zaveze po Melkizedekovem redu s svojim telesom in krvjo. Ta daritev je bila skrita pod podobo vseh daritev stare zaveze. Tudi v psalmu slišimo glas Srednika, ki preroško oznanja: "Žgalnih daritev in daritev za greh nisi hotel, a telo si mi pripravil« (Ps 40.7), kajti na mesto vseh drugih daritev se daruje njegovo telo in ga delijo udeležencem (O božjem mestu 17.20.2).

96 Velikonočno jagnje je povezovalni člen odrešenjskega dogodka: pri hebrejski pashi je podoba na križu darovanega Kristusa, pravega Jagnjeta; pri krščanski evharistiji je pravo darovano jagnje tisto, ki smo ga deležni. 
Ko je hiponski škof pisal prijatelju Pavlinu iz Nole, je spregovoril o stiski, ki jo povzroča vprašanje, ali je nujno kaznovati določene krivde. To je velika skrivnost, pravi (Pismo 95.3), saj je potrebno upoštevati, koliko notranje moči ima grešnik. Bi lahko prenašal kazen ali pa bi jo zavrnil. Avguštinove smernice so jasne:

noben greh ni tak, da ga Cerkev ne bi mogla odpustiti. Prešuštvo, umor, bogoskrunstvo so težke smrtne rane, vendar imamo Zdravnika, ki zmore vse (Govor 352.2.8). Poslanstvo Cerkve je vedno namenjeno odrešenju človeka.

Excommunicatio, izobčenje ima zdravilen namen, ni kazen sama v sebi, zato je vedno začasna. Izobčenje je ved no vezano na odpuščanje (Pismo 265.7). Prednost ima vedno kriterij usmiljenja, ne disciplinarni ukrep.

Prenašati je treba tiste, ki ne sprejmejo izobčenja in se obnašajo, kot da se ni nič zgodilo. Prenašati pa je potrebno tudi tiste, ki namesto javne pokore sprejmejo alternativno (Govor 82.3-7). Pot pokore je za vernika vedno pot vere in vrnitve $\mathrm{k}$ svobodi.

V praksi je Avguštin prenesel pokoro za nekatere grehe iz javne v privatno sfero. Na ta način je tudi konkretno Cerkev postala posrednica milosti prelite krvi Odrešenika za odpuščanje grehov. ${ }^{97}$

\section{AVGUŠTINOVI POUDARKI, KI JIH RAZBEREMO NA OZADJU GOVOROV 272 IN 227}

Razodetje, ki nas uvaja v božje skrivnosti za odrešenje sveta, je podano v znamenjih. ${ }^{98}$ Znamenj je v Stari zavezi veliko, v Novi zavezi pa jih je manj, vendar so ta novozavezna znamenja bližja srčiki razodetja. Avguštin z besedo sacramenta označi ne le obrede Nove zaveze, temveč tudi Stare, ker se nanašajo na Kristusa in na obljubo njegovega prihoda. V zgodovini božjega ljudstva Avguštin prepozna mnoge zakramente, vidni svet odseva zakramentalni svet, svet vere, svet odrešenjske ojkonomije učlovečenja in velikonočne skrivnosti. Kristus sam je božji zakrament, velik in neizrekljiv zakrament (sacramentum Dei, magnum et inenarrabile sacramentum, Sermo 91.3). Zato je razumljivo, da evharistija zavzame posebno mesto med zakramenti, ki so znamenja, ki zadevajo božje stvari (signa, quae cum ad res divinas pertinent, sacramenta appellantur, Ep. 128.7).

Avguštin pravi, to misel smo zasledili v Govorih 272 in 227 , da je evharistija zakrament Kristusovega telesa, ki se je učlovečil po Devici Mariji in se daroval na križu, pa tudi celotnega Kristusa, Glave in udov njegovega mističnega telesa. Učinek, ki ga povzroča moč zakramenta (virtus sacramenti), je v tem, da so po evharistiji udje resnično povezani s Kristusom, kot z Gla-

97 Grossi, „Note al binomio "Sangue sparso e remissione dei peccati” sino a s. Agostino«, 1231. 98 Sage, "L’Eucaristie dans la pensée de saint Augustin«, 218-19. 
vo. Vredno prejemanje zakramenta zagotavlja tesno pripadnost udov Glavi in globlje prejemanje božjega življenja. Pojmovanje Cerkve kot občestva udov Kristusovega telesa, katerega Glava je sam Kristus, ni postransko, temveč središčno v Avguštinovi teologiji. Hiponski škof vedno govori o Kristusu, naj gre za Glavo ali za ude, vedno poudarja enost in edinost njegovega telesa, za katero rad uporablja simbol kruha in vina, ki predstavljata pot iz različnosti v enotnost. Za to da bi Avguštin izrazil to enost, uporablja ti naravni prvini (kruh in vino), ki obstajata pred posvetitvijo, ki v sebi nimata virtus sacramenti. ${ }^{99}$ Znotraj mistagoške kateheze za novokrščence je torej povsem razumljiv in pomenljiv poudarek na občestvu, na ljubezni in na večnem življenju. Če so verniki del Kristusovega telesa, so posledično tudi sami prineseni na oltar v kruhu in kelihu. Kristus zbere v sebi vse ude in jim posreduje svoje življenje. Tako jih tudi povezuje med seboj.

Kruh in vino po posvetilni molitvi postaneta nekaj drugega (aliud), Kristusovo telo in kri. Ta spremenitev je delo Svetega Duha, ${ }^{100}$ to je trditev vere, čeprav si Avguštin prizadeva, da bi doumel to, v kar veruje. Delo Svetega Duha ni vidno, kakor nista vidna telo in kri, ne včlenitev udov v Glavo mističnega telesa. Zato razumevanje vere ne more nikoli do konca razpršiti skrivnostnosti evharistije, ki je ne moremo doumeti po mesu (carnaliter), kakor je nekoč niso mogle množice v Kafarnaumu. Avguštin vpričo donatistov zavrne trditev, da heretiki in shizmatiki vredno (digne) in učinkovito uživajo zakrament edinosti. Kdor bo kakor koli jedel Gospodovo meso in pil njegovo kri, ne bo ostal v Kristusu ne Kristus v njem, ampak le tisti, ki bo to delal na določen način, kakor pravi v Govoru $71.11 .17{ }^{101}$

\section{Vpliv doktrinarnih razprav}

Iz Avguštinovih spisov zoper manihejstvo, donatizem in pelagijanstvo je razvidno, da so bile te polemike zanj tudi priložnost za poglobitev nauka o evharistični skrivnosti. ${ }^{102}$ Ko je pisal proti manihejcem, je poudarjal kontinuiteto med Staro in Novo zavezo in dokazal, da so bile izraelske daritve, čeprav na zunaj podobne poganskim daritvam, namenjene Bogu in so vnaprej kazale na daritev, ki jo sedaj daruje Cerkev. Kristus je v svoji daritvi storil neizmerno več kot Mojzes za odrešenje celotnega ljudstva.

V primeru donatizma je bila že sama tematika bolj povezana z evharistijo. Avguštin je priznal, da so donatisti imeli Sveto pismo, oznanjali Kristusovo oznanilo, pristno obhajali zakramente, toda niso imeli bratske ljubezni.

\footnotetext{
99 Boyer, »'́eucharistie selon saint Augustin«, 131-33.

100 V zvezi s tem glej: Sage, »L’Eucaristie dans la pensée de saint Augustin«, 224.

101 "Non ergo quocumque modo quisquam manducaverit carnem Christi et biberit sanguinem

Christi, manet in Christo et in illo Christus, sed certo quodam modo« (Sermo 71.11.17).

102 Sage, "L'Eucaristie dans la pensée de saint Augustin«, 214.
} 
Njihov zavesten in hoten prelom s Cerkvijo je bil velika ovira za pristnost zakramentov. ${ }^{103}$ Kristusova beseda in ne svetost delivca zakramenta naredi zakrament za sveto znamenje. Kristusova beseda veže božjo moč (virtus divina) na sestavine, ki so namenoma izbrane zaradi naravnega simbolnega pomena: voda očiščuje, kruh in vino hranita. Gospodova beseda pričuje o navzočnosti Duha svetosti, ljubezni in edinosti v zakramentih Cerkve. S svojim notranjim razpoloženjem se vernik pridruži Duhu svetosti, ko pri krstu zavrne grešno življenje, in Duhu bratske ljubezni v edinosti Cerkve, ko pri evharistiji prejme Kristusovo telo in kri, sicer ne obhaja zakramenta duhovno, temveč le po črki. Peter in Juda ${ }^{104}$ sta med učenci primer, kako je človek lahko na različen način deležen evharistije. Od leta 400 oz. 401 naprej se Avguštin usmerja k duhovnemu in dinamičnemu pojmovanju evharistije. ${ }^{105}$

Tudi polemika s pelagijanci ni bila brez posledic za nauk o evharistiji, saj le-ti starozaveznim in novozaveznim daritvam oz. zakramentom niso priznavali pravega pomena. Pravični iz Stare zaveze so zgled pravičnosti, ki nič ne dolguje Kristusu, zato Pelagij trdi, da more človek vedno živeti svetost brez Kristusa, saj se vsak rodi v popolni neokrnjenosti naravnih darov. Toda Avguštin je ugovarjal, da je že apostol Pavel učil, da je bil Kristus navzoč in da je deloval preko postave, ki je vnaprej naznanjala njegov prihod. Poleg tega je bil prepričan, da na zemlji ni nikogar, ki ne bi potreboval odpuščanja, zato je vsak dan pri oltarju potrebno moliti za to. Avguštin je jasno izpovedal nauk, ki ga je razglasil koncil v Kartagini leta 411, o nujnosti Kristusa in zakramentov krsta in evharistije za odrešenje.

Po prvih letih škofovstva (397-410) se je Avguštin neposredno soočil z vprašanji, ki so jih postavili donatisti in pelagijanci med leti 411 in $413 \cdot{ }^{106}$ Leta 400 ugovarja donatističnemu škofu Parmenijanu in izpostavlja, da je Kristus kot veliki duhovnik ${ }^{107}$ edini Srednik, ki je vstopil v pravo svetišče, daroval pravo daritev in grešnim udom svojega telesa omogočil zrenje Boga. Leta 411 odgovarja na vprašanja Marcelina in poudari, da je Kristus nebeški Srednik, edini brez greha, edini popoln in da popolnost ni utemeljena na človeških močeh. On je Srednik pri Očetu za človeštvo in neprestano posreduje zanj. Teološke razprave so gotovo vplivale na določene poudarke njegovega nauka: Kristus je popolnoma brez greha, hkrati pa popolnoma solidaren z ljudmi. ${ }^{108}$

103 Avguštin v homilijah o kruhu življenja poudarja vez med evharistijo in edinostjo: vabi, naj si novokrščeni prizadevajo biti eno kot Kristusovo telo, da bo evharistija zanje postala večna hrana (Sage, »L'Eucaristie dans la pensée de saint Augustin«, 230-31).

104 Avguštin večkrat in v različnih delih v povezavi z Gospodovo večerjo razpravlja o Judu Iškarijotu kot o enem izmed apostolov, ki je prav kot tak Kristusa izdal. V zvezi s tem glej: Di Nola, La dottrina eucaristica, 27-29.

105 Sage, »L’Eucaristie dans la pensée de saint Augustin«, 214-16.

106 Quinot, „L'influence de l'Épître aux Hébreux«, 153.

107 Avguštinovi razlagalci so vedno poudarjali vpliv Pisma Hebrejcem na njegov evharistični nauk. Sacerdos magnus je naziv, ki ga v Novi zavezi Kristusu pripisuje le omenjeno pismo (Van der Lof, »Eucaristie et présence réelle«, 303).

108 Ker je Bog, bi lahko le sprejel daritev, toda raje jo je daroval (Boyer, „L'eucharistie selon saint Augustin«, 125). 


\section{Teologija edinosti in daritve}

Estote quod videtis, et accipite quod estis - pravi Avguštin v Govoru 272; si bene accepistis, vos estis quod accepistis - pa ponavlja v Govoru 227. Ta dva govora dejansko združi evharistična tematika, ki se osredotoči na resničnost in znamenje edinosti. S soteriološkega vidika namreč Avguštin predpostavlja edinost, ki je sad božjega odrešenjskega delovanja v Kristusu. Z eklezialnega vidika pa se Avguštin zaveda, da je zaradi shizmatičnih zapletov resničnost edinosti vedno na preizkušnji in močno prizadeta. Razumljivo je, da je škof v teh govorih hotel novokrščence vzpodbuditi, da bi si z vsemi močmi prizadevali za obnovo in rast edinosti, ki je izraz ontološke spremembe, ki so je bili deležni po zakramentih uvajanja: postali so namreč udje Kristusovega telesa, eno v Kristusu.

Estote quod videtis, et accipite quod estis lahko razumemo kot etični imperativ: »Bodite, kar vidite, in prejmite, kar ste!« Si bene accepistis, vos estis quod accepistis pa lahko razumemo kot odrešenjski indikativ, ki utemeljuje bistvo Cerkve: »Vi ste to, kar ste prejeli«, pod pogojem, da ste vredno prejeli, torej z vzpodbudo za preverjanje notranjega razpoloženja in življenja v edinosti ter s prošnjo k Bogu, da bi Cerkev uresničevala to, kar ji je Gospod zapovedal. Ta dinamika med imperativom in indikativom je prepoznavna v Pavlovi teologiji, ${ }^{109}$ ko apostol na njej utemeljuje potrebo po doslednosti med Gospodovo večerjo in obnašanjem znotraj krščanske skupnosti (1 Kor 10.17) ter dolžnost izogibati se razprtij in ločin (1 Kor 11.18-19). ${ }^{10}$ Prav tako ta dinamika odpira pogled na eshatološko razsežnost vprašanja edinosti, ki je že uresničena, ni pa še dopolnjena. Glede na ozadje obeh Avguštinovih govorov pa ta dinamika dobi prav bogat doktrinalen pomen.

Evharistija je pristna in velika skrivnost ljubezni, simbol edinosti in vez ljubezni. Verniki resnično poznajo Kristusovo telo, če si prizadevajo biti Kristusovo telo. ${ }^{111}$ Kruh in vino, pravi Avguštin, nedvomno izražata notranjo povezanost med telesom in udi, v katerih je Cerkev. Vez med evharistijo in ljubeznijo je tesna, kajti evharistija, ki nas združuje, nas napravi za Kristusove ude in za njegov tempelj. Zato morajo verniki ljubiti edinost in se bati ločitev. Prav takšna tesna vez obstaja med evharistijo, vero in razumom. V kolikor smo po veri združeni s Kristusom, smo oživljeni po razumu.

109 Velja poudariti, da je za Pavla človeško prizadevanje rodovitno samo takrat, ko črpa iz božjih odrešenjskih moči, iz moči Svetega Duha, torej se etični imperativ prepleta s klicem k Bogu za njegovo odrešenjsko delo (Schnackenburg, Messaggio morale del Nuovo Testamento, 254). Indikativ pa vedno izraža zastonjski dar božjega odrešenja.

110 Postati Kristusovo telo vključuje dolžnost prizadevati si tudi za premoščanje družbenih razlik, sicer evharistija ni v resnici živeta kot zakrament ljubezni. Te duhovne in družbene razsežnosti evharistične teologije so v Avguštinovem času zelo poudarjene tudi pri Janezu Krizostomu. Za poglobitev: Hamman, Korenine naše vere, 137-51.

111 Di Nola, La dottrina eucaristica, 24-25. 
Evharistija je tudi daritev. Kristus je znova darovan in sacramento med evharistično daritvijo. On daruje daritev občestva svetih, v katero vstopa daritev kristjanov, ki sestavljajo eno samo telo. ${ }^{112}$ Tako se Cerkev daruje skupaj z njim. ${ }^{113}$ Ta daritev kristjanov je zakrament Kristusove daritve. Obstaja torej eksistencialna vez med evharistično daritvijo in daritvijo kristjana, ki daruje samega sebe. Evharistija je imenovana sacrificium, v Govoru 227 pa je izrecno rečeno, da smo božja daritev mi sami. ${ }^{114}$ Povezavo med daritvijo kristjana in Cerkve ter daritvijo Kristusa moramo torej brati v luči povezave med zakramentom odrešujočega učlovečenja in zakramentom Kristusovega telesa in krvi, ki je evharistija. Odrešenje, kot smo omenili že v uvodu, ima torej dve plati: kristološko in antropološko.

Za kristološko razsežnost je temeljnega pomena pojem sredništva. ${ }^{115}$ Srednik je edini, ki ontološko stoji na sredi in s svojim delovanjem lahko spravi v eno dve skrajnosti. Človek je srednik med telesnimi in duhovnimi stvarmi. Srednik odrešenja stoji med Bogom in človekom, je solidaren $\mathrm{z}$ Bogom in $\mathrm{s}$ človekom, je nesmrten z Bogom, smrten s človekom. Kristus je hkrati totus Deus et totus homo, edini in popoln srednik odrešenja (1 Tim 2.5), da bi človeka osvobodil greha in smrti ter ga pridružil božji pravičnosti in večnosti. Človek je po Sredniku rešen, ko je osvobojen od svoje revščine in je deležen božjih dobrin. Brez Srednika, pravi Avguštin, nihče ni bil in ne bo osvobojen, saj človeški rod nikoli ni bil brez te vedno odprte odrešenjske poti, ki je Kristus sam. Njegovo odrešenje je za vse čase in rodove, ne le za izvoljeno ljudstvo. ${ }^{116}$ Tudi sredi drugih narodov je namreč nekaj "pristnih Izraelcev«, ki so meščani nebeškega Jeruzalema. To je možno le zato, ker jim je bil razodet edini Srednik med Bogom in človekom, Jezus Kristus Gospod. On je izvir odrešenja in milosti za vse človeštvo, tudi tisto, ki je živelo pred Kristusovim učlovečenjem. Nihče ni rešen brez Kristusa, ki izvršuje svoje sredništvo na spoznavni ravni s tem, da človeku razodene Sveto Trojico, na soteriološki ravni s tem, da ga na križu spravi z Bogom in z drugimi. Po Kristusovem sredništvu Sveta Trojica ustvarja edinost človeštva. On je torej središče edinosti. ${ }^{117}$

Antropološka razsežnost Avguštinove teologije odrešenja pa osvetljuje njegovo povezavo med krivdo in kaznijo. Zaradi te povezave so posledice Adamovega greha $\mathrm{v}$ človeku ne samo smrt in poželenje, ampak tudi zazna-

\footnotetext{
112 Sage, »L'Eucaristie dans la pensée de saint Augustin«, 221-22.

113 Poudarjeno je, da je s Kristusom kot Christus totus tudi Cerkev duhovnik in daritev ter se udeležuje odrešenjskega delovanja Srednika, ki je univerzalna pot odrešenja (dell'Osso, »Il Christus totus «, 345).

114 Pellegrino, Introduzione generale, LI.

115 Trapè, »S. Agostino", 408-10.

116 Tukaj se odpira zelo široko vprašanje izvoljenosti Izraela in poklicanosti narodov, oz. konkretno, zakaj je Bog izbral Jakoba in ne Ezava, zakaj je faraon zakrknil srce (2 Mz 9.16 in Rim 9.17) itd., se pravi razmerje med milostjo, predestinacijo in svobodno voljo. To razmišljanje je Avguštin vse bolj poglabljal glede na doktrinalno ozadje, bodisi protignostično, bodisi protimanihejsko, bodisi protipelagijansko (Mara, Agostino interprete di Paolo, 225-29).

117 Cipriani, Molti e uno solo in Cristo, 93-101.
} 
movanost z izvirnim grehom. Avguštin utemeljuje izvirni greh s teologijo odrešenja in krsta. Njegova teološka argumentativna metoda ne gre od greha do odrešenja, temveč obratno od odrešenja do greha. Pelagijanska polemika se je vrtela okrog dileme, ali odrešenje pomeni le udeležbo pri božjem občestvu ali pa tudi osvoboditev od zla. Te zadnje osvoboditve pelagijanci niso priznavali. Avguštin pa preiskuje Sveto pismo in biblično utemeljuje, da sta oba vidika neločljivo vključena v Kristusovo odrešenjsko delovanje. Kristus nas je oživil, odrešil, osvobodil, razsvetlil zato, ker smo bili v smrti, sužnosti, ječi, temi greha. Kristus je umrl zaradi odpuščanja grehov, zaradi sprave človeštva $\mathrm{z}$ Bogom, ki je zaradi izvirnega greha živelo v sovraštvu z njim. Kristus je torej edini odrešenik in njegovo odrešenje potrebujejo vsi.

Iz tega sledi, da Kristus, novi Adam, ni enostavno dober zgled za človeštvo glede na prvega človeka, ki je dal slab zgled. To pelagijansko postavitev hiponski škof odločno zavrne, kajti to bi izvotlilo celoten krščanski nauk. Kristus nas ni odrešil z zgledom, temveč z daritvijo na križu, s prelito krvjo. Človekovo posvečevanje ni le sad zgledovanja po Kristusu, torej sad človeških prizadevanj in naporov. Gre za opravičenje, novo rojstvo na križu po daritvi Srednika, ki je hkrati žrtev, duhovnik, daritev, ki služabnike spremeni v božje otroke. On se je daroval za vse, kajti vsi so umrli zaradi greha, tudi otroci. Gre za univerzalnost odrešenja in od tod izpeljano univerzalnost izvirnega greha.

\section{Razvoj nauka}

Razlagalci ${ }^{118}$ predpostavljajo nekakšen razvoj Avguštinovega evharističnega nauka v smislu, da naj bi hiponski škof najprej podal simbolično razlago tega zakramenta, ko poudari vernikovo prizadevanje za pridruženje Kristusu, potem pa realističen pristop, ko poudari vlogo samega mesa (caro) Odrešenika, ki podeli milost občestva z njim. Ta prehod, ki božje delovanje postavlja na prvo mesto, je razložljiv v okviru polemike proti Pelagiju. Dejansko razlagalci prepoznavajo v Avguštinovem nauku o evharistiji naslednje poudarke: to, kar je le kruh in vino, po posvetitvi in delovanju Svetega Duha postane meso in kri Jezusa Kristusa. To je zakrament njegovega telesa in krvi, kajti to, kar vidimo in otipamo, je znamenje tega, kar je tam navzoče. Toda Kristus je hotel pridružiti vse vernike $\mathrm{k}$ sebi in jim podeliti svoje življenje, ki v njih postane poroštvo večnega življenja. V evharistiji je navzoč celoten Kristus. Njegovi udje morajo biti že združeni z njim, da bi ga vredno prejeli in tako ostali $\mathrm{v}$ njem, kakor on ostaja v njih. Kristus je hotel postaviti daritev nove zaveze.

118 Karl Adam je med razlogi za ta razvoj omenil Avguštinovo platonsko formacijo, ki naj bi jo premostil ob branju homilij Janeza Krizostoma, ob katerem se je naučil pripisati mesu Boga-človeka duhovno razsežnost. Boyer je mnenja, da je Avguštin platonizem zavrnil v 8. knjigi dela O božjem mestu ter da je poskus Karla Adama, ki se je skliceval na kronologijo Avguštinovih del, pomanjkljiv. Tudi Boyer pa se strinja z omenjenim razvojem v evharističnem nauku (Boyer, "L'eucharistie selon saint Augustin«, 136-37). 
Duhovnik in žrtev daruje Očetu svoje meso in kri, kakor se je daroval že na križu, ter s seboj in po sebi daruje svoje mistično telo, ki je Cerkev. Za vernike je evharistija udeležba pri Odrešenikovi daritvi. Ta nauk je utemeljen na spremenitvi kruha in vina v Kristusovo telo in kri. ${ }^{119}$

Branje Govora 272 in Govora 227 nam je omogočilo preveriti takšen prehod v Avguštinovem nauku. Videli smo namreč, da sta ti dve evharistični katehezi zelo podobni in podata skoraj isto vsebino, če izvzamemo poudarek o Kristusovi krvi, preliti za nas v odpuščanje grehov, in poziv, naj si človek ne pripisuje zaslug, temveč spozna, da je božji dar imeti srce kvišku. Poleg pojma edinosti je v Govoru 227 izpostavljen pojem odrešenjske moči. Dinamika med imperativom in indikativom, ki smo jo prepoznali v Avguštinovih besedah Estote quod videtis, et accipite quod estis, in Si bene accepistis, vos estis quod accepistis, lahko kaže na nov spoznavni dejavnik. Avguština namreč skrbi opredelitev razmerja med božjim deležem v odrešenjskem načrtu oz. med božjim darom in človekovim deležem pri tem, tj. delež njegove svobodne volje, njegovih zaslug in doprinosa.

Ta prehod je potrjen tudi, ko pogledamo kronologijo, ki jo strokovnjaki predlagajo za oba govora: Govor 272 (405-411) in Govor 227 (412-413, 416, 417). Gotovo je dogajanje leta 411 pomenilo odločilen dejavnik v Avguštinovem teološkem razpravljanju pri reševanju različnih zmot.

Sinoda leta 411 je bila v Kartagini sklicana po ukazu cesarja Honorija z namenom, da reši donatistični razkol. Zbralo se je 286 katoliških in 279 donatističnih škofov. V afriški Cerkvi sta bila skoraj povsod hkrati dva škofa, katoliški in donatistični. Sinoda se je po zaslugi trdne biblične osnove in govorniške sposobnosti hiponskega škofa zaključila z zelo hudimi ukrepi proti donatistom in predvsem $\mathrm{z}$ jasno določitvijo teoloških postavk: izključitev iz Cerkve ni posledica greha, niti smrtnega in javnega, ampak odpada od vere; svetost delivca oz. njegovo notranje stanje (stanje milosti) ni pogoj za veljavnost zakramenta.

Leta 411 je bila prav tako v Kartagini t.i. collatio carthaginensis proti Pelagijevemu prijatelju Celestiju, ki je z njim prišel v Afriko, potem ko sta leta 410 zbežala iz Rima. Prej sta namreč v Italiji svobodno razširjala svoja krivoverska prepričanja. Leta 415 sta sledila dva koncila v Jeruzalemu in Diospolisu, na katerih je bil Pelagijev nauk razglašen za pravovernega, toda papež Zosim je z okrožnico Epistola tractoria poleti leta 418 dokončno zavrnil njegovo teologijo kot heretično. Avguštinovo prizadevanje za poglobitev nauka mu je pridobilo naziv »učitelj milosti«. Nihče namreč ni tako jasno iz Svetega pisma in izročila Cerkve potegnil pravoverno teologijo o izvirnem grehu, o nepogrešljivi vlogi krsta in o delovanju milosti (gratia preveniens in gratia adiuvans) za človekovo odrešenje. ${ }^{120}$

119 Boyer, "L’eucharistie selon saint Augustin«, 136-38. 120 Grossi, »Avversari e amici di Agostino«, 450-55. 


\section{SKLEP}

Zavedamo se, da so Avguštinova besedila, ki se nanašajo na evharistični nauk in teologijo, zelo številna in razpršena po vseh njegovih spisih. Razsežnosti pričujoče naloge so omogočile le bežen pogled dveh govorov in njunega ozadja, tako da smo lahko zaslutili globino nauka tega »izrednega filozofa, teologa, asketa in predvsem gorečega dušnega pastirja «. ${ }^{121}$ Izrecno evharistični poudarki se prepletajo s soteriološkimi, kristološkimi, ekleziološkimi in eshatološkimi.

Sintezo njegovega evharističnega nauka je posredoval 2. vatikanski cerkveni zbor v Konstituciji o svetem bogoslužju, 47-48:

Naš Odrešenik je pri zadnji večerji, tisto noč, ko je bil izdan, postavil evharistično daritev svojega telesa in svoje krvi, da bi s tem daritev na križu mogla trajati skozi vse čase, dokler ne pride, in da bi tako Cerkvi, svoji ljubljeni nevesti, zaupal spomin svoje smrti in svojega vstajenja: zakrament dobrotljivosti, znamenje edinosti, vez ljubezni, velikonočno gostijo, v kateri se prejema Kristus, duša napolnjuje z milostjo in nam daje poroštvo prihodnje slave. Zato si Cerkev skrbno prizadeva, da verniki tej skrivnosti vere ne bi prisostvovali kot tuji ali nemi gledalci, ampak da bi jo v obredih in molitvah dobro razumeli; zavestno, pobožno in dejavno naj bi sodelovali pri svetem dogajanju; se dali oblikovati božji besedi in se krepili ob mizi Gospodovega telesa. Zahvaljevali naj bi se Bogu in darovali brezmadežno žrtev ne le po mašnikovih rokah, ampak združeni z njim in se s tem naučili darovati tudi sami sebe. Tako naj bi se po Kristusu sredniku vsak dan bolj použivali v edinost z Bogom in med seboj, da bo končno Bog vse v vseh.

Božje delovanje teži torej $\mathrm{k}$ temu, da bi ljudje, ki nas je mnogo, postali eno, da bi uresničevali božje hrepenenje, da bi bil on vse v vseh. ${ }^{122}$

Videli smo tudi Avguštinovo ponižnost pred božjo skrivnostjo, ki je razodeta v Svetih spisih in v zakramentih, saj se je hiponski škof zavedal nepremostljivih meja človekovega razuma pred božjo trascendenco. ${ }^{123}$ Načelo podobnosti (similitudo), ki je bilo v antiki uporabljeno na področju spoznavanja in ki sta ga Ambrož in Avguštin uveljavljala za krščanske zakramente, ${ }^{124}$ pride do izraza prav v razmerju podobnosti med evharistijo in Cerkvijo, kakor se izkaže v obeh govorih. Polemika proti donatistom je to razmerje še bolj poudarila v smislu enosti, saj, kakor mora biti prava daritev le ena, tako mora biti eno tudi samo občestvo Cerkve, ki jo daruje. Znani vzklik »sacramentum pietatis, signum unitatis, vinculum caritatis" iz homilije 26 Govorov o Janezovem evangeliju, ki jo je Avguštin verjetno napisal po letu 413 (in prej kot leta 
421), že kaže na poenoteno cerkveno občestvo, saj je leta 411 sinoda v Kartagini pravno rešila razdeljenost v afriški Cerkvi.

Iz obravnavanih govorov je razvidno, da ima Avguštin dve glavni kategoriji, enost in Kristusovo telo. Gospodovo telo je hkrati evharistični kruh in Cerkev, saj bi bila nerazumljiva, če bi ju ločili. Enost, za katero je Kristus molil v velikoduhovniški molitvi ( Jn 17), je skrivnost obnovljene prvotne enosti, ki jo je človeštvo zgubilo z Adamom in ki vse ude Cerkve združuje po Svetem Duhu, ki deluje kot duša v njej. Gre za ontološko enost, ne za skupek ljudi, gre za božji dar enosti, ki ima pnevmatološko počelo. Ta enost ima družbeno in duhovno razsežnost, je enost materialnih dobrin in obenem zakramentalna enost. Kristusovo telo je za Avguština vedno vezano na Cerkev. Kristus-glava in Cerkev-telo tvorita celega Kristusa (Christus totus), to je skrivnost, ki je bila vnaprej napovedana v Adamu in Evi. Ta povezava med Kristusovo enostjo in Cerkvijo se razkriva $\mathrm{v}$ evharistiji ${ }^{125}$ in odpira eshatološko razsežnost božjega kraljestva, ko bo možno uživati polnost tega občestva.

Pri vsakdanjem obedu je človek v središču, v kolikor uživa hrano, ki postane del njegovega telesa. V evharistiji pa je Kristus navzoč in njegova navzočnost ni statična, temveč dinamična. On nas pritegne k sebi in nas asimilira, on je v središču in nas želi združiti, da bi bili eno z njim. To je proces spremenjenja, ki posebej pritegne našo pozornost. ${ }^{126}$ Pri evharistiji je človeku podana največja možnost spremenjenja. Kénosis Božjega Sina (Flp 2.7) se po Avguštinu uresničuje prav kot spremenjenje, najprej v učlovečenju, potem pa v smrti in vstajenju, saj mutatio vultus Christi ni samo skrivnost ponižanja, temveč tudi vstajenja in poveličanja. Te tri etape so združene pri mašni daritvi, kjer Kristus »sedaj« izvršuje svoje duhovništvo po Melkizedekovem redu in uresničuje spremenjenje. Avguštinov pristop k evharistiji poudarja ne zgodovinski trenutek Kristusove smrti in vstajenja, temveč odrešenjsko dejanje, zato je Kristusova daritev na križu vedno aktualna in realna. ${ }^{127}$ Zakramentalni dar Kristusovega telesa in krvi je največje spremenjenje (mutatio), po katerem znotraj zakramenta evharistije Kristus spreminja kruh in vino v novo daritev. Trikrat se Kristus poniža: v učlovečenju, na križu in v evharistiji, ki

125 Za enost Cerkve Avguštin uporablja simbol Kristusove suknje, ki je bila brez šiva, od vrha scela stkana, medtem ko njegova vrhnja oblačila, ki so jih vojaki razdelili na štiri dele, predstavljajo univerzalnost Cerkve (Ceriotti, L'unità di Cristo, 94). Donatistom tako pripiše krivdo razdelitve Cerkve. Podobo edinosti Cerkve kot Kristusove suknje, ki je niso razdelili niti vojaki pod križem, torej kot notranjega bistva Cerkve, je prvič uporabil Ciprijan ( $O$ edinosti 7 ).

126 Pri evharistiji kruh in vino postaneta Kristusovo telo in kri. Spremenjenje naravnih, običajnih dobrin kruha in vina v Kristusovo telo in kri v moči občestva Svete Trojice vključuje tudi dinamizem, ki spreminja resničnost v njeni kozmični, človeški in zgodovinski razsežnosti. Preko njega spremenjenje v občestvo doseže vse udeležence evharistije. To skrivnost zelo jasno izraža Avguštin v Izpovedih (7.10.16), kjer pripoveduje, da je spoznal, kako daleč je od Gospoda in se mu je zdelo, kot da sliši njegov glas iz višine: »Kruh velikih sem: zrasti pa me boš užival. Vendar se ne bom jaz spremenil vate, kakor se jed tvojega mesa, ne, ti se boš spremenil vame! (»Cibus sum grandium: cresce et manducabis me. Nec tu me in te mutabis sicut cibum carnis tuae, sed tu mutaberis in me.«) Za trinitaričnost evharistije glej: Sorč, »Evharistija dar svete Trojice in zahvala Cerkve«, $75-82$.

127 Bergeron, »La doctrine eucharistique de l'Enarratio in Ps. 33 d'Augustin«, 104-108. 
je največje dejanje ponižnosti. Tam je tudi izvir človekove ponižnosti. V evharistiji se Kristus spreminja in vzame nase obličje ponižnosti, da bi mi prepoznali obličje slave.

Eshatološko občestvo z Bogom v Kristusu je končni cilj Kristusovega odrešenjskega načrta. Evharistično občestvo je poroštvo tega eshatološkega občestva, je že znamenje obljubljene dopolnitve, ki se mora še uresničiti, zato je novozavezna daritev popolnoma drugačna od starih daritev. Novokrščeni se pripravljajo, da bi vredno prejeli ta eshatološki dar, da bi začeli pot k popolnosti v Cerkvi, da bi se obljubljeno občestvo čimbolj udejanjilo v življenju. Ta napetost med prejemom Kristusovega telesa in uresničenjem Kristusovega telesa je zajeta v Avguštinovo misel: »Bodite, kar vidite, in prejmite, kar ste.» Tukaj je tudi njegov klic k vztrajnosti v iskanju edinosti in klic k svetosti življenja.

$\mathrm{V}$ ta proces spremenjenja je povabljen vsakdo, ki pristopi k evharistični mizi. Evharistija namreč dopolnjuje proces kristifikacije krščenca, to je proces tiste duhovne poti, na kateri se kristjan vedno globlje zaveda, da je po krstu včlenjen v Kristusovo telo, ki je Cerkev, in je poklican to tudi uresničevati, da bi v resnici živel v Kristusovem telesu. Iz udeležbe pri evharistiji izhaja bistvena posledica za vsakdanje življenje posameznika in občestva: enost, ki je istovetna $\mathrm{z}$ mirom. Avguštin se večkrat vrača k temu vidiku, kajti razkol in razprtije so ranile Kristusovo telo. ${ }^{128} \mathrm{~V}$ kolikor ima Avguštin pred očmi občestvo, razdeljeno pred letom 411, ima njegova kateheza stvarni pastoralni namen in ob zakramentu evharistije poziva k uresničevanju načela edinosti. Ko pa se po letu 411 sooča s »strupom« pelagijanstva, ki prav tako vnaša razdejanje v občestvo, poudarja univerzalnost odrešenja in poziva k sprejetju soteriološke moči evharističnega zakramenta. V tem primeru je jasno, da se Avguštin navezuje na Kristusa, edinega Srednika odrešenja in na evharistično daritev v njegovem telesu, ki je Cerkev.

Simbolika kruha služi za upodobitev edinosti krščanske skupnosti in močne vezi, ki združi zakramentalno in mistično telo. Kristjani so deležni mističnega telesa, obenem pa zajemajo iz zakramentalnega telesa, iz evharistije. Zato kristjani hkrati prejmejo Kristusovo telo in so to, kar prejmejo. $S$ tem, da vredno prejmejo, utrdijo edinost Cerkve. Ker je evharistija daritev celega telesa, tudi sami darujejo svoje telo v sveto, čisto, Bogu všečno daritev in sami izvršijo svoje duhovništvo. Tako se milost zakramenta razširja na vse ustvarjeno za osredinjenje vseh stvari v Kristusu. ${ }^{129}$ Iz te milosti izhaja kristološki, soteriološki, ekleziološki in eshatološki sad evharistije.

128 dell'Osso, »Il Christus totus", 340-43.

129 Turnšek, »Zakramenti«, 180; 283-87. 


\section{BIBLIOGRAFIJA}

Avrelij Avguštin. Izpovedi. Prevedel Anton Sovre. Priredil Kajetan Gantar. Celje: Mohorjeva družba, 1984.

Bareille, G. »Eucharistie d'après les Pères. «V: Dictionnaire de théologie catholique, ur. A. Vacant, E. Mangenot in E. Amann, V, 1. Paris: Letouzey, 1903-1972.

Bergeron, Richard. »La doctrine eucharistique de l'Enarratio in Ps. 33 d'Augustin.« Revue des Études Augustiniennes 19 (1973): 101-20.

Boyer, Charles. »L'eucharistie selon saint Augustin.«Augustinus XII (1967): 125-38.

Brown, Peter. La vie de saint Augustin. Paris: Éditions du Seuil, 2001.

Caruso, Giuseppe. "L'Eucaristia nella riflessione di Agostino." Alpha omega 11 (2008): $13-36$.

Cattaneo, Enrico. »"In unum congregans". La supplica per il raduno della chiesa nelle preghiere eucaristiche.« Rassegna di Teologia 28 (1987): 345-73.

Cattaneo, Enrico. »Dalla parola all'eucaristia. Un esempio di «trasformazione» di un testo e di una pratica."Rassegna di Teologia 46 (2005): 5-15.

Ceriotti, Giancarlo. L'unità di Cristo secondo Sant'Agostino. Roma: Città Nuova, 2009.

Cipriani, Nello. Molti e uno solo in Cristo. La spiritualità di Agostino. Studi Agostiniani 16. Roma: Città Nuova Editrice, 2009.

Daniélou, Jean. »La catéchèse dans la tradition patristique.« V: L'initiation chrétienne, ur. A. Hamman, 7-20. Paris: Bernard Grasset Èditeur, 1963.

de Bruyne, Lucien. "L'initiation chrétienne et ses reflets dans l'art paléochrétien.« Revue des Sciences Religieuses 36, št. 3/4 (1962): 27-85.

dell'Osso, Carlo. »Il "Christus totus": Chiesa ed Eucaristia in alcuni testi in S. Agostino.« Rivista di Scienze Religiose 18 (2004): 337-53.

De Lubac, Henri. Corpus Mysticum. L'Eucaristia e la Chiesa nel Medioevo. Teologia incammino 3. Tr. it. Torino: Piero Gribaudi Editore,1968.

de Luis, Pio. "La Eucaristía, Sacramentum pietatis. Estudio agustiniano 41 (2006): 4560.

Didahe. V: Spisi apostolskih očetov, prev. Fran Omerza idr. Celje: Mohorjeva družba, 1996.

Di Nola, Gerardo. La dottrina eucaristica di Sant'Agostino. Città del Vaticano: Libreria Editrice Vaticana, 1997.

Drobner, Hubertus R. Patrologia. Casale Monferrato: Edizioni Piemme,1998.

Frend, W. H. C. »Donatismo.« V: Dizionario Patristico e di Antichità Cristiane, ur. A. Di Berardino, I-III. Casale Monferrato: Edizioni Piemme, 1983-1988.

Folliet, Georges. »Une définition augustinienne du sacrament de l'eucharistie.» Revista Agustiniana XLV (2004): 519-52.

Grossi, Vittorino. "Avversari e amici di Agostino.« V: Patrologia. I Padri latini (secoli $I V-V), 434-475$, ur. Angelo Di Berardino. Casale Monferrato: Marietti, 1978.

Grossi, Vittorino. »Pelagio - Pelagiani - Pelagianesimo.«V: Dizionario Patristico e di Antichità Cristiane, ur. A. Di Berardino, I-III. Casale Monferrato: Edizioni Piemme, 1983-1988.

Grossi, Vittorino. "Note al binomio "Sangue sparso e remissione dei peccati" sino a s. Agostino.« V: Sabgue e antropologia. Riti e culto, 5/II, 1221-1231, ur. F. Vattioni. Roma: Pia Unione Prez.mo Sangue, 1987.

Grossi, Vittorino. "L'Eucaristia in S. Agostino.« V: Dizionario di spiritualità biblico-patristica, vol. 20, L'eucaristia nei Padri della Chiesa, 261-270. Roma: Borla, 1998. 
Grossi, Vittorino, ur. Sant'Agostino. L'Eucaristia, corpo della chiesa. Roma: Città Nuova, 2000.

Hamman, Adalbert G. »Eucaristia.« V: Dizionario Patristico e di Antichità Cristiane, ur. A. Di Berardino, I-III. Casale Monferrato: Edizioni Piemme, 1983-1988.

Hamman, Adalbert G. La vita quotidiana nell'Africa di S. Agostino. Milano: Jaka Book, 1989.

. Korenine naše vere. Prevod Miran Špelič. Ljubljana: Družina, 1993.

Koncilski odloki, konstitucije, odloki, izjave, poslanice 2. vatikanskega vesoljnega cerkvenega zbora (1962-1965). Ljubljana: Družina, 1980, ${ }^{1} 1995 .{ }^{2}$

Kunzelmann, Adalbero. »Die Chronologie der Sermones des Hl. Augustinus.« V: Studi Agostiniani, Miscellanea Agostiniana, vol. 2, 417-520. Roma: Tipografia Poliglotta Vaticana, 1931.

Mara, Maria Grazia. Agostino interprete di Paolo. Milano: Figlie di San Paolo, 1993.

Marafioti, Domenico. »Eucaristia e Chiesa. L'esegesi di sant'Agostino al cap. 6 del Vangelo di san Giovanni.« Rassegna di Teologia 47 (2006): 103-16.

Opere di Sant'Agostino. Discorsi IV/1 (184-229/V). Nuova Biblioteca Agostiniana. Roma: Città Nuova Editrice, 1984.

Opere di Sant'Agostino. Discorsi IV/2 (230-272/B). Nuova Biblioteca Agostiniana. Roma: Città Nuova Editrice, 1984.

Quinot, Bernard. »L’influence de l'Épître aux Hébreux dans la notion augustinienne du vrai sacrifice."Revue des Études Augustiniennes VIII, 1 (1962): 129-68.

Panizzolo, Sandro. »Gli elementi essenziali della communio secondo i Padri.« V: Ecclesia Tertii Millenni Advenientis, Fs. Angel Antón, 266-275, ur. F. Chica, S. Panizzolo in H. Wagner. Casale Monferrato: Edizioni Piemme, 1997.

Pasquato, Ottorino. »Eucaristia e Chiesa in Agostino.« Ephemerides liturgicae 102 (1988): 46-63.

Pellegrino, Michele. Introduzione Generale. V: Opere di Sant'Agostino, Discorsi I (1-50), IX-CII. Nuova Biblioteca Agostiniana 29. Roma: Città Nuova Editrice, 1979.

Poque, Suzanne. »Introduction.« V: Augustin D'Hippone, Sermons pour la Pâque, 9-143. Sources chrétiennes 116. Paris: Les Éditions du Cerf, 1966.

Ratzinger, Joseph. La comunione nella Chiesa. Cinisello Balsamo: Editrice San Paolo, 2004.

Sage, Athanase. »L'Eucharistie dans la pensée de saint Augustin.« Revue des Études Augustiniennes XV 1-2 (1969): 209-40.

Schnackenburg, Rudolf. Messaggio morale del Nuovo Testamento, tr. it. Alba: Paideia Edizioni, 1971.

Sorč, Ciril. »Evharistija dar svete Trojice in zahvala Cerkve.« Communio 10, št. 1 (2000): $73-89$.

Špelič, Miran. »Evharistija pri cerkvenih očetih.«Tretji dan 3/4 (2005): 63-67.

Trapè, Agostino. "S. Agostino.« V: Patrologia. I Padri latini (secoli IV-V), 323-434, ur. Angelo Di Berardino. Casale Monferrato: Marietti, 1978.

Trapè, Agostino. »Agostino d'Ippona." V: Dizionario Patristico e di Antichità Cristiane, ur. A. Di Berardino, I-III. Casale Monferrato: Edizioni Piemme, 1983-1988.

Turnšek, Marjan. »Zakramenti.« V: Priročnik dogmatične teologije, 153-342, ur. Ciril Šorč. Ljubljana: Družina, 2003.

Van Der Lof, L. Johan. »Eucharistie et présence réelle selon saint Augustin.«Revue des Études Augustiniennes X (1964): 295-304. 


\section{"ESTOTE QUOD VIDETIS, ET ACCIPITE QUOD ESTIS«: L'EUCARISTIA IN AURELIO AGOSTINO}

Riassunto

La ricerca è nata in occasione del XVI centenario della Conferenza di Cartagine del 411 d.C., che per Agostino segnò la conclusione della controversia donatista. Ma la fine di quella polemica segnava al contempo l'inizio di un'altra. Nello stesso anno infatti si affacciava all'orizzonte la delicata questione dell'ortodossia di Pelagio, su cui il pensatore di Ippona dovette riflettere a lungo, orientando il successivo sviluppo della dottrina e della prassi fino ad oggi. Filologi e teologi hanno sottolineato spesso un dinamismo interno al pensiero di Agostino. L'obiettivo principale della ricerca è appunto quello di verificare l'evolversi della riflessione agostiniana a causa del contesto storico in cui le opere vennero alla luce. A questo scopo sono stati individuati due dei quattro sermoni che l'Ipponense dedicò alla mistagogia eucaristica, i Discorsi 272 e 227, attraverso i quali è possibile seguire la linea di evoluzione suddetta, essendo stati scritti rispettivamente prima e dopo il 411 d.C.

La prima parte dell'articolo contestualizza i due sermoni, illuminandone l'ambiente liturgico, polemico e teologico di composizione. La seconda e la terza parte presentano la traduzione in lingua slovena e il commento rispettivamente dei Discorsi 272 e 227 . Infine si delineano i principali aspetti che emergono dalla dottrina eucaristica agostiniana, nella fattispecie si definiscono i concetti fondamentali della teologia sacramentale di Agostino (rapporto res - signum, fides - ratio, virus - fructus sacramenti), evidenziando l'aspetto ecclesiale e soteriologico della sua dottrina eucaristica. La ricerca si sofferma sulle conseguenze delle polemiche dottrinali: sebbene i due sermoni appaiano simili nel presentare l'eucaristia ai neofiti, in realtà al Discorso 272 fa da specchio una situazione ecclesiale scismatica, di fronte alla quale Agostino sottolinea l'aspetto comunionale del sacramento, dunque l'eucaristia come mysterium unitatis. Dall'analisi del Discorso 227 invece emerge la sottolineatura di un altro aspetto, quello del sacramentum redemptionis, dal momento che l'eucaristia è definita rispetto al tema del sangue sparso e della gratuità della salvezza. La controversia donatista, quindi, nel primo caso e quella pelagiana nel secondo hanno giocato un ruolo determinante nella riflessione dogmatica e, di conseguenza, nell'attività di predicazione, catechesi, mistagogia del vescovo di Ippona. Lo spartiacque è dato proprio dagli avvenimenti storici dell'anno 411 nell'Africa di Aurelio Agostino.

Questo percorso di ricerca è necessario per poter comprendere fino in fondo il senso della notissima espressione agostiniana, riportata anche nel Discorso 272: Estote quod videtis, et accipite quod estis, nonché la variazione 
presente nel Discorso 227: Si bene accepistis, vos estis quod accepistis, dunque l'intreccio storico tra realismo e dinamismo, tra il già soteriologico e il non ancora escatologico. 